Cover: Groundwater sampling at Ellsworth Air Force Base. Photograph taken by Joshua F. Valder, U.S. Geological Survey, on July 13, 2021. 


\section{Groundwater Assessment for Petroleum Hydrocarbon Compounds Associated with Fuels Area C, Ellsworth Air Force Base, South Dakota, 2014-18}

By David A. Bender, Joel M. Galloway, and Colton J. Medler

Prepared in cooperation with Defense Logistics Agency and Ellsworth Air Force Base

Scientific Investigations Report 2021-5060 


\section{U.S. Geological Survey, Reston, Virginia: 2021}

For more information on the USGS - the Federal source for science about the Earth, its natural and living resources, natural hazards, and the environment—visit https://www.usgs.gov or call 1-888-ASK-USGS.

For an overview of USGS information products, including maps, imagery, and publications, visit https://store.usgs.gov/.

Any use of trade, firm, or product names is for descriptive purposes only and does not imply endorsement by the U.S. Government.

Although this information product, for the most part, is in the public domain, it also may contain copyrighted materials as noted in the text. Permission to reproduce copyrighted items must be secured from the copyright owner.

Suggested citation:

Bender, D.A., Galloway, J.M., and Medler, C.J., 2021, Groundwater assessment for petroleum hydrocarbon compounds associated with Fuels Area C, Ellsworth Air Force Base, South Dakota, 2014-18: U.S. Geological Survey Scientific Investigations Report 2021-5060, 37 p., https://doi.org/10.3133/sir20215060.

Associated data for this publication:

Medler, C.J., Tatge, W.S., and Bender, D.A., 2021, Electrical Resistivity Tomography (ERT) and Horizontal-to-Vertical Spectral Ratio (HVSR) data collected within and near Ellsworth Air Force Base, South Dakota, from 2014 to 2019: U.S. Geological Survey data release, https://doi.org/10.5066/PgXSJH17.

U.S. Geological Survey, 2020, USGS water data for the Nation: U.S. Geological Survey National Water Information System database, https://doi.org/10.5066/F7P55KJN.

ISSN 2328-0328 (online) 


\section{Contents}

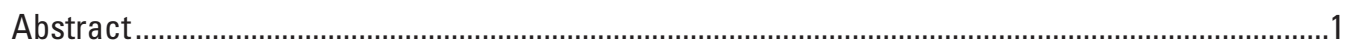

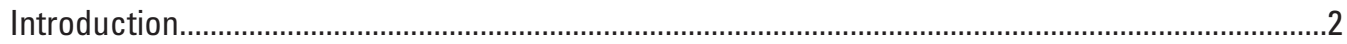

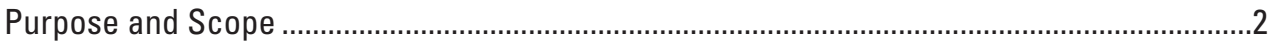

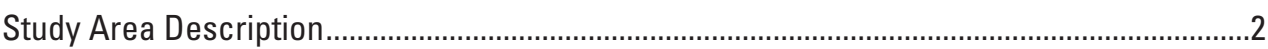

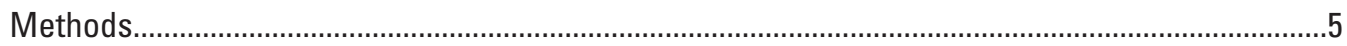

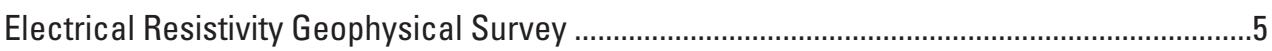

Monitoring Well Installation and Site Selection.................................................................

Generalized Potentiometric-Surface and Groundwater-Flow Determination...........................8

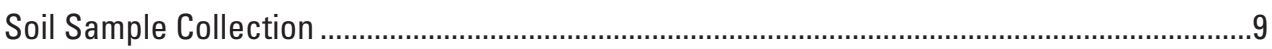

Groundwater-Quality Sample Collection ................................................................................

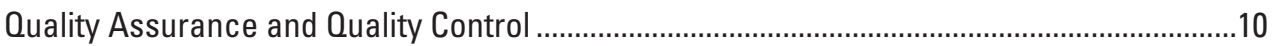

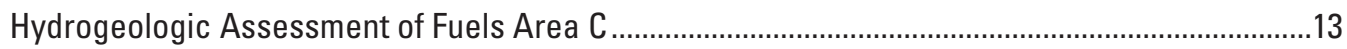

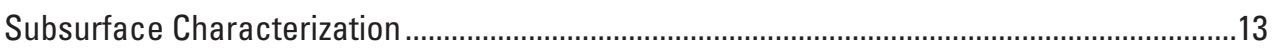

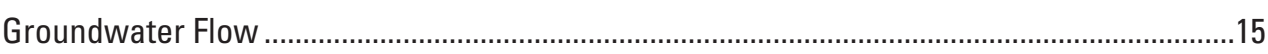

Assessment of Petroleum Hydrocarbons within and near Fuels Area C .....................................18

Petroleum Hydrocarbons in Soils ...................................................................................18

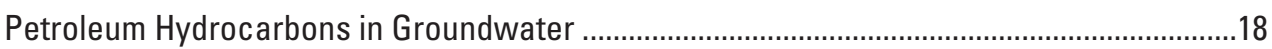

Benzene, Toluene, Ethylbenzene, Xylene, and Naphthalene ........................................18

Gasoline-Range and Diesel-Range Organics ..............................................................27

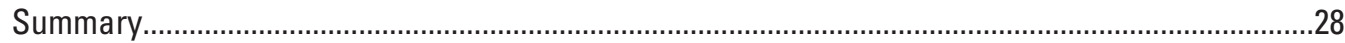

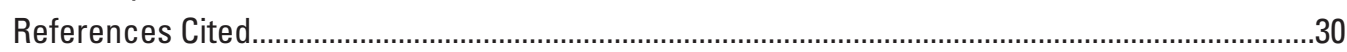

Appendix 1. Water-Level Data around Fuels Area C, 2014-18_.................................................32

Appendix 2. Water-Quality Data around Fuels Area C, 2014-18 ...................................................37

\section{Figures}

1. Map showing study area including Fuels Area $C$ and groundwater-monitoring wells around Fuels Area C on Ellsworth Air Force Base, South Dakota .............................3

2. Resistivity inversion results for electrical resistivity survey lines in the study area around Fuels Area C

3. Map showing generalized potentiometric surface estimated for the alluvial aquifer in the study around Fuels Area C, 2014-18

4. Maps showing number and location of detections for BTEX compounds in samples collected at sites in the study area around Fuels Area C, 2014-18.

5. Map showing number and location of detections of naphthalene in samples collected in the study area around Fuels Area C, 2014-18

6. Boxplots showing distribution of gasoline-range and diesel-range organic compound concentrations in 14 monitoring wells and a recovery sump sampled in the study area around Fuels Area C, 2014-18. 


\section{Tables}

1. Summary of the petroleum hydrocarbon spills and releases in the study area around Fuels Area C from 1992 to 2016, Ellsworth Air Force Base, South Dakota . .4

2. Site information for 14 monitoring wells and a recovery sump sampled in the study area around Fuels Area C, 2014-18.

3. Constituents selected for analyses of soil and groundwater samples collected in the study area around Fuels Area C, 2014-18.

4. Results of field blank and trip blank samples collected at sites in the study area around Fuels Area C, 2014-18.

5. Relative percent differences of concentrations between replicate and environmental sample pairs for samples collected at monitoring well site 1 within Fuels Area C, 2014-18

6. Mean water-level and hydraulic head data used to construct a generalized potentiometric-surface map of the alluvial aquifer in the study area around Fuels Area C, 2014-18

7. Summary of petroleum hydrocarbon compound concentrations in soil samples collected at 11 sites in 2014 and 2016 in the study area around Fuels Area C

8. Summary of petroleum hydrocarbon compound concentrations in groundwater samples collected from 14 monitoring wells and a recovery sump in the study area around Fuels Area C, 2014-18

\section{Conversion Factors}

International System of Units to U.S. customary units

\begin{tabular}{|c|c|c|}
\hline Multiply & By & To obtain \\
\hline \multicolumn{3}{|c|}{ Length } \\
\hline millimeter (mm) & 0.03937 & inch (in.) \\
\hline meter (m) & 3.281 & foot (ft) \\
\hline kilometer (km) & 0.6214 & mile (mi) \\
\hline \multicolumn{3}{|c|}{ Area } \\
\hline square meter $\left(\mathrm{m}^{2}\right)$ & 0.0002471 & acre \\
\hline square kilometer $\left(\mathrm{km}^{2}\right)$ & 247.1 & acre \\
\hline \multicolumn{3}{|c|}{ Volume } \\
\hline liter $(\mathrm{L})$ & 33.81402 & ounce, fluid (fl. oz) \\
\hline liter (L) & 0.2642 & gallon (gal) \\
\hline \multicolumn{3}{|c|}{ Pressure } \\
\hline kilopascal (kPa) & 0.009869 & atmosphere, standard (atm) \\
\hline kilopascal (kPa) & 0.2961 & inch of mercury at $60^{\circ} \mathrm{F}$ (in $\mathrm{Hg}$ ) \\
\hline
\end{tabular}

Temperature in degrees Celsius $\left({ }^{\circ} \mathrm{C}\right)$ may be converted to degrees Fahrenheit $\left({ }^{\circ} \mathrm{F}\right)$ as follows:

$$
{ }^{\circ} \mathrm{F}=\left(1.8 \times{ }^{\circ} \mathrm{C}\right)+32 .
$$




\section{Datum}

Vertical coordinate information is referenced to the North American Vertical Datum of 1988 (NAVD 88).

Horizontal coordinate information is referenced to the North American Datum of 1983 (NAD 83).

Altitude, as used in this report, refers to distance above the vertical datum.

\section{Supplemental Information}

Specific conductance is given in microsiemens per centimeter at 25 degrees Celsius $(\mu \mathrm{S} / \mathrm{cm}$ at $25^{\circ} \mathrm{C}$ ).

Concentrations of chemical constituents in water are given in either milligrams per liter (mg/L) or micrograms per liter $(\mu \mathrm{g} / \mathrm{L})$, and concentrations in soils are given in milligrams per kilogram $(\mathrm{mg} / \mathrm{kg})$. 


\section{Abbreviations}

\begin{tabular}{ll} 
BTEX & benzene, toluene, ethylbenzene, and xylene \\
C6 & six-carbon chain hydrocarbon \\
C10 & ten-carbon chain hydrocarbon \\
DLA & Defense Logistics Agency \\
D0 & dissolved oxygen \\
DR0 & diesel-range organic \\
EAFB & Ellsworth Air Force Base \\
EPA & U.S. Environmental Protection Agency \\
ERT & electrical resistivity tomography \\
GNSS & global navigation satellite system \\
GRO & gasoline-range organic \\
JP-4 & jet propellant-4 \\
JP-8 & jet propellant-8 \\
LRL & laboratory reporting level \\
MCL & maximum contaminant level \\
NAD 83 & North American Datum of 1983 \\
NAVD 88 & North American Vertical Datum of 1988 \\
PID & photoionization detector \\
PVC & polyvinyl chloride \\
PTFE & polytetrafluoroethylene \\
OC & quality control \\
RMS & root mean square \\
RTK & real-time kinematic \\
SC & specific conductance \\
SDDENR & South Dakota Department of Environment and Natural Resources \\
TPH & total petroleum hydrocarbon \\
USGS & U.S. Geological Survey \\
UST & underground storage tank \\
VOC & volatile organic compound \\
\hline D.
\end{tabular}




\title{
Groundwater Assessment for Petroleum Hydrocarbon Compounds Associated with Fuels Area C, Ellsworth Air Force Base, South Dakota, 2014-18
}

\author{
By David A. Bender, Joel M. Galloway, and Colton J. Medler
}

\section{Abstract}

In 2013, the U.S. Geological Survey began a study in cooperation with the Defense Logistics Agency and the U.S. Air Force to estimate groundwater-flow direction, install groundwater monitoring wells, and collect soil and groundwater samples for petroleum hydrocarbon compounds to identify the presence of hydrocarbon contamination at Ellsworth Air Force Base, South Dakota, specifically around Fuels Area C. Several fuel spills of diesel fuel, jet fuel, and other petroleum products were documented on or near Fuels Area C and several studies have been done to determine the extent of petroleum hydrocarbon contamination in the subsurface.

Two-dimensional electrical resistivity tomography surveys were completed at Fuels Area C in 2014 to characterize subsurface materials and determine the depth to bedrock along survey lines. The depth to the top of the Pierre Shale from land surface along the four electrical resistivity tomography survey lines in Fuels area $\mathrm{C}$ ranged from about 5.4 to 8.7 meters. Resistivity lines and lithologic logs in wells in the area indicated mostly clay material with minor occurrences of sand and gravel.

Discrete groundwater levels were collected between November 2014 and June 2018 at 14 monitoring wells for use in generating a potentiometric surface in the study area around Fuels Area C. The potentiometric contours indicated that groundwater flow was from the west to east or southwest to southeast around Fuels Area C.

Soil and groundwater samples were collected at selected locations from 2014 to 2018 to better understand the presence and movement of petroleum hydrocarbons in the study area around Fuels Area C. Soil samples were collected at eight wells during installation in 2014 and three wells during installation in 2016. Groundwater samples were collected from 14 wells and a recovery sump around Fuels Area C from 2014 to 2018.

Several petroleum hydrocarbon compounds were detected, but below action levels, in soil samples collected in 2014 and 2016. Benzene and toluene were not detected in any of the soil samples from the 11 monitoring well sites. Ethylbenzene and total xylenes were detected at sites 1 and
7. Naphthalene was detected in samples from five sites (sites $1,5,7,8$, and 9), but concentrations were less than the Tier 1 action level of 25 milligrams per kilogram.

Gasoline-range organic compounds were detected in all soil samples collected during the installation of 11 groundwater monitoring wells within or near Fuels Area C in 2014 and 2016. Diesel-range organic compounds were detected in 9 out of the 11 soil samples collected at the 11 monitoring wells. Gasoline-range organic compound concentrations exceeded the Tier 2 assessment level for total petroleum hydrocarbons in soil samples from site 1 (5,200 milligrams per kilogram), site 5 (580 milligrams per kilogram), and site 9 (1,800 milligrams per kilogram); the remaining sites had concentrations below the Tier 2 assessment level for total petroleum hydrocarbons. The highest concentrations of diesel-range organic compounds in soil samples were from site 1 (3,600 milligrams per kilogram), site 5 (440 milligrams per kilogram), and site 14 (330 milligrams per kilogram), and only the sample from site 1 exceeded the Tier 2 assessment level for total petroleum hydrocarbons.

Petroleum hydrocarbon concentrations were measured in samples collected from 14 groundwater monitoring wells and 1 recovery sump between 2014 and 2018 in the study area around Fuels Area C. Benzene, toluene, ethylbenzene, and xylene (BTEX) compounds were detected in at least one sample collected from 10 of the 15 sites sampled in the study area from 2014 to 2018. Samples from monitoring well sites 2, $3,6,8$, and 9 did not have any quantifiable concentrations of BTEX compounds. Multiple BTEX compounds were detected consistently in samples collected from sites 10 and 11. Few BTEX compounds were detected at sites outside of and downgradient from Fuels Area C (sites 12-14). Naphthalene was detected in 8 of the 15 sites sampled in the study area in 2014-18. Measurable concentrations of naphthalene generally were less than 5 micrograms per liter in wells sampled in the study area in 2014-18 except for samples collected at sites 5, 7 , and 11 .

The variability of the presence of BTEX compounds and naphthalene in wells sampled in the study area during 2014-18 likely is caused by the variability in the subsurface material, local groundwater flow, operational fueling activities, 
and historical spills and releases in the area. The spatial and temporal variability in the BTEX compounds and naphthalene concentrations from samples collected from 2014 to 2018 do not indicate a consistent pattern of subsurface flow or contaminate movement that would be expected if a contaminant plume migrated with the flow and movement of groundwater.

Gasoline-range organic and diesel-range organic compounds were detected in most of the groundwater samples collected in the study area around Fuels Area C in 2014-18; however, concentrations were often less than the laboratory reporting level. Median gasoline-range organic compound concentrations were greater than the laboratory reporting level at sites $1,5,9,10$, and 11 . The highest concentrations of gasoline-range organic and diesel-range organic compounds generally were observed in samples collected from sites 10 and 11. Gasoline-range organic compound concentrations ranged from 1,500 to 9,700 micrograms per liter at site 10 and from less than 100 to 13,000 micrograms per liter at site 11 . Diesel-range organic compound concentrations ranged from 9,600 to 55,000 micrograms per liter at site 10 and from 560 to 7,300 micrograms per liter at site 11 .

\section{Introduction}

Ellsworth Air Force Base (EAFB) is approximately 10 kilometers (6 miles) northeast of Rapid City, South Dakota. The base includes about 20 square kilometers (about 5,000 acres) of land in Meade and Pennington Counties. The base supports a runway, airfield operations, maintenance complexes, industrial areas, housing, and recreational facilities. In 2013, the base hosted a population of about 9,000 people including military, family members, and civilian employees (Powers, 2013).

The base operates and maintains equipment, facilities, and infrastructure to store and transport aviation fuels, gasoline, and diesel fuels for aircraft, vehicle, and other energy needs. Some of the storage areas were constructed in the 1950s and present the base with several maintenance and environmental challenges (U.S. Air Force, 2012). Aboveground and underground movement and storage of large volumes of fuels, fuel spills, seepage from underground-storage tanks, and unintentional leaks from former aboveground storage tanks within Fuels Area $\mathrm{C}$ are potential point-sources for contamination of the groundwater in the area.

Several fuel spills of diesel fuel, jet fuel (jet propellant-4 [JP-4], jet propellant-8 [JP-8], and Jet A), and other petroleum products were documented on or near Fuels Area C (South Dakota Department of Environment and Natural Resources, 2020), and several studies have been done to determine the extent of petroleum hydrocarbon contamination in the subsurface (Tetra Tech Incorporated, 2008, 2012). Findings from previous soil samples and groundwater samples within Fuels Area C indicated that leakage of JP-8 and other fuels was associated with two existing underground storage tanks
(USTs) (Tetra Tech Incorporated, 2008). Jet fuel, such as JP-8, is a complex mixture of petroleum hydrocarbons and hundreds of additional compounds that may vary in composition (Custance and others, 1992). Compounds in JP-8 that are concerns to human health include benzene, toluene, ethylbenzene, and xylene (BTEX), naphthalene, and other total petroleum hydrocarbons (TPHs) such as gasoline and diesel. The study described in this report was done to further understand hydrocarbon movement and occurrence in the groundwater around Fuels Area C.

In 2013, the U.S. Geological Survey (USGS) began a study in cooperation with the Defense Logistics Agency (DLA) and the U.S. Air Force to estimate groundwater-flow direction, install groundwater monitoring wells, and collect soil and groundwater samples for petroleum hydrocarbon compounds to identify the presence of the hydrocarbon contamination at EAFB, specifically around Fuels Area C. Fuels Area $\mathrm{C}$ is near the south boundary of EAFB west of Ellsworth Street (fig. 1). Since construction, Fuels Area $\mathrm{C}$ has stored several types of aviation fuel including JP-4, JP-8, and Jet-A. Also, diesel fuel and deicing fluids were stored in smaller quantities at aboveground tanks, although the aboveground tanks have been removed from the site (fig. 1).

\section{Purpose and Scope}

The purpose of this report is to describe the methods used to collect data for assessing petroleum hydrocarbon conditions in the groundwater around Fuels Area C from 2014 to 2018 and the results of the assessment. Two-dimensional electrical resistivity tomography (ERT) surveys were conducted at Fuels Area C in 2014 to characterize subsurface materials and determine the depth to bedrock along survey lines. Discrete water-level data were collected between November 2014 and June 2018 to estimate the potentiometric surface and groundwater-flow direction in the study area. Soil-quality data were collected during the installation of 11 monitoring wells, and groundwater-quality samples were collected from 14 monitoring wells and a recovery sump between November 2014 and June 2018. Soil and groundwater samples were analyzed for BTEX compounds, $m$ - and $p$-xylene, $o$-xylene, naphthalene, gasoline-range organic (GRO) compounds, and dieselrange organic (DRO) compounds.

\section{Study Area Description}

Fuels Area C (fig. 1) was constructed in about 1953 and has operated nearly continuously since construction (Tetra Tech Incorporated, 2008). The area is west of Ellsworth Street and covers about 0.3 square kilometer (79 acres; fig. 1). A small unnamed ephemeral stream is east of Fuels Area C, and Gateway Lake (not shown on figure) is northeast of the area. Prairie Ridge Golf Course is about 265 meters (m; 870 feet [ft]) east of Fuels Area C. 


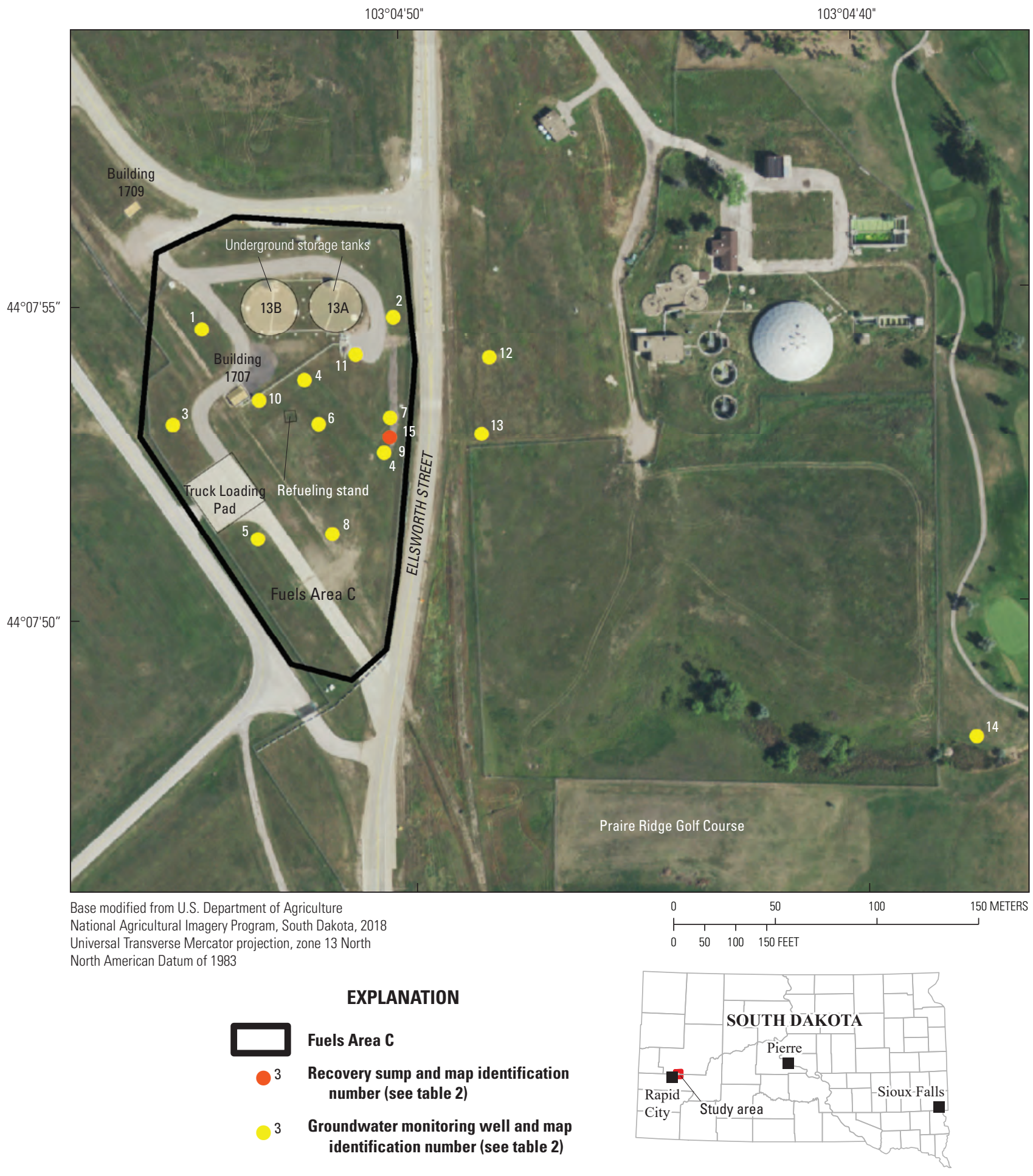

Figure 1. Study area including Fuels Area $C$ and groundwater-monitoring wells around Fuels Area $C$ on Ellsworth Air Force Base, South Dakota. 
Jet fuel and diesel fuel were delivered to Fuels Area $\mathrm{C}$ by tanker truck and rail-line tankers in the past; however, Jet-A fuel currently (2020) is delivered to the USTs in Fuels Area C by pipeline (Jens Christensen, Environmental Restoration Program Manager, Ellsworth Air Force Base, oral commun., 2019). Fuels Area $C$ has been used to store and transfer jet fuels, diesel fuel, aviation gasoline, and vehicle gasoline (Tetra Tech Incorporated, 2008) using aboveground storage tanks and USTs. Aboveground storage tanks were in the northwest and center parts of Fuels Area $\mathrm{C}$ but were demolished in June 2001 (Tetra Tech Incorporated, 2008). However, two 3.2 million-liter (840,000-gallon) USTs remain operational and in use in Fuels Area C (fig. 1). As of 2020, the two USTs store aviation turbine fuel Jet A (Jens Christensen, Environmental Restoration Program Manager, Ellsworth Air Force Base, oral commun., 2019).
Several petroleum releases have been documented, including diesel fuel, jet fuel (JP-4, JP-8, and Jet A), and other petroleum products on or near Fuels Area C (table 1). On June 3, 2015, approximately 3,400 liters (900 gallons) of Jet A were released to the subsurface from UST 13B (fig. 1, table 1). Petroleum product from the June 2015 spill migrated to a collection system under USTs 13A and 13B (BERS-Weston Services JVA, LLC, 2016). The collection system was connected to a storm drain that discharged near the Prairie Ridge Golf Course to the southeast of Fuels Area C (fig. 1). A recovery sump was installed in the storm drain in November 2015 to capture the water and fuel from the collection system and pump it to a treatment facility (BERS-Weston Services JVA, LLC, 2016).

Table 1. Summary of the petroleum hydrocarbon spills and releases in the study area around Fuels Area C from 1992 to 2016, Ellsworth Air Force Base, South Dakota.

[MM, month; DD, day; YYYY, year; --, no information available; JP, jet propulsion, BTEX, benzene, toluene, ethylbenzene, xylene; TPH, total petroleum hydrocarbons; mg/kg, milligram per kilogram; UST, underground storage tank]

\begin{tabular}{|c|c|c|c|c|}
\hline $\begin{array}{l}\text { Date } \\
\text { (MM/DD/ } \\
\text { YYYY) }\end{array}$ & Type of spill & Location & Description & $\begin{array}{c}\text { Spill } \\
\text { identification } \\
\text { number }\end{array}$ \\
\hline 11/12/1992 & $\begin{array}{l}227 \text { liters ( } 60 \text { gallons) of } \\
\text { diesel fuel }\end{array}$ & $\begin{array}{l}\text { Refueling stand located in } \\
\text { Fuels Area C }\end{array}$ & -- & 92.383 \\
\hline 03/15/1993 & $\begin{array}{l}\text { 1,893 liters (500 gallons) } \\
\text { of JP-4 }\end{array}$ & $\begin{array}{l}\text { Building } 1707 \text { located in } \\
\text { Fuels Area C }\end{array}$ & $\begin{array}{l}\text { Free liquid was recovered and the soil was } \\
\text { excavated along the spill route. In } \\
\text { June 1995, } 15 \text { direct push soil borings } \\
\text { were installed at the site to determine the } \\
\text { extent of the } 1993 \text { JP-4 fuel release. BTEX } \\
\text { and TPH exceedance concentrations were } \\
\text { observed in several locations. }\end{array}$ & 93.055 \\
\hline 09/19/1994 & $\begin{array}{l}30 \text { liters ( } 8 \text { gallons) of } \\
\text { diesel fuel }\end{array}$ & $\begin{array}{l}\text { Truck loading pad with } \\
\text { Fuels Area C }\end{array}$ & $\begin{array}{l}\text { TPH concentrations were detected in all the } \\
\text { 1-foot sample intervals ranging in concen- } \\
\text { tration from } 2.7 \text { to } 172.3 \mathrm{mg} / \mathrm{kg} \text {. This case } \\
\text { was closed on April } 28,2000 \text {. }\end{array}$ & 94.349 \\
\hline 06/03/2015 & $\begin{array}{l}\text { 3,407 liters (900 gallons) } \\
\text { of jet fuel (Jet A) }\end{array}$ & $\begin{array}{l}\text { Release to the subsurface } \\
\text { from west UST (UST 13B) } \\
\text { located at Fuels Area C }\end{array}$ & $\begin{array}{l}\text { Several investigative activities were conducted } \\
\text { to determine the extent of the effects related } \\
\text { to the release of fuel from the UST, includ- } \\
\text { ing direct push sampling of subsurface } \\
\text { soils and groundwater, and soil and surface } \\
\text { water sampling to assess the spill effects. A } \\
\text { long-term recovery sump was installed in } \\
\text { the storm drain to capture the drainage from } \\
\text { the underground drainage system beneath } \\
\text { the USTs. }\end{array}$ & 2015.096 \\
\hline
\end{tabular}

${ }^{1}$ South Dakota Department of Environment and Natural Resources, 2020. 
Subsurface lithology can affect the movement of contaminants in groundwater in the study area. The geology around EAFB consists of about $260 \mathrm{~m}(860 \mathrm{ft}$ ) of Cretaceousage Pierre Shale (bedrock) overlain by surficial deposits that are predominately alluvium (McGregor and Cattermole, 1973; Rahn and Glick, 2000). The alluvium consists of sand, silt, clay, and gravel that range in depth from about 3 to $12 \mathrm{~m}$ (10 to $40 \mathrm{ft}$; Tetra Tech Incorporated, 2008). Based on descriptions of soil borings from previous studies, the alluvial textures are highly variable in the area of Fuels Area C (Tetra Tech Incorporated, 2008).

Groundwater wells were used in the study area to monitor the extent and movement of petroleum hydrocarbons in the subsurface, including existing wells and wells that were installed as part of the study described in this report. Monitoring well sites 10 and 11 were used in studies from 2008 and 2011 (fig. 1; table 2; Tetra Tech Incorporated, 2008, 2012). Nine additional monitoring wells were installed in November 2014 (sites 1-9; fig. 1; table 2) and another three wells were installed in December 2016 (sites 12-14; fig. 1; table 2).

\section{Methods}

This section describes the methods used for an ERT geophysical survey, collection of groundwater-level information and development of a generalized potentiometric surface, and the collection of soil and groundwater-quality samples. The methods include geophysical survey procedures, monitoring well installation and site selection, potentiometric surface mapping processes, and water-quality sample collection procedures. The study results provide improved understanding of groundwater conditions in the study area around Fuels Area $\mathrm{C}$ and the migration and presence of petroleum hydrocarbons in the subsurface.

\section{Electrical Resistivity Geophysical Survey}

Two-dimensional ERT surveys were conducted at Fuels Area $\mathrm{C}$ in 2014 to characterize subsurface materials and determine the depth to bedrock along survey lines. The ERT methods measure horizontal or vertical changes in resistivity of the subsurface that typically correspond to changes in lithology, chemistry of pore fluids, and water content of subsurface materials (Sheets, 2002). Two-dimensional ERT surveys commonly are accomplished using several electrodes equally spaced along a straight line (Loke, 2000, 2004). The spacing of electrodes along a survey line affects the depth of investigation and the measurement resolution - greater electrode spacing corresponds to greater depth of investigation but less measurement resolution and shorter electrode spacing corresponds to lesser depth of investigation but greater measurement resolution (Loke, 2000, 2004). Electrodes are connected to a console that automatically selects four electrodes for each measurement. Measurements consist of two current electrodes and two potential electrodes; electrical current is transmitted into the subsurface through current electrodes and the resulting voltage is measured at the potential electrodes (Loke, 2000, 2004). Electrode groupings and the sequence of measurements are controlled by the type of array specified for the survey. Commonly used arrays include Wenner, dipole-dipole, and Schlumberger (Loke, 2000, 2004). The ERT data are downloaded from the console after the survey is complete and modeled using inversion software to obtain two-dimensional cross-sections of the subsurface resistivity distribution.

Electrical resistivity data were collected in the study area between July 24 and 25, 2014, using an 8-channel, 56-electrode SuperSting R8 (Advanced Geosciences Incorporated, 2020a). Stainless steel electrodes were connected to stainless steel stakes placed along predetermined survey lines and were evenly spaced by 2 to $3.5 \mathrm{~m}$. The electrodes were then connected to the SuperSting R8 console that automatically collected resistivity data by toggling electrical pulses between programmed combinations of current and potential electrode pairs based on the dipole-dipole array configuration. The dipole-dipole array was selected because of its high resolution and multichannel capability that provides a detailed image of the subsurface (Loke, 2000). Survey lines RL1 and RL3 required the "roll-along" technique to extend the horizontal area covered by the survey. The "roll-along" technique involved moving the electrode cable at the front of the survey to the end of the survey line while the end line was still in place. The roll-along technique was repeated until the desired length of survey line was achieved. Survey lines lengths ranged from about 80 to $172.5 \mathrm{~m}$.

Real-time kinematic (RTK) surveying methods with global navigation satellite system (GNSS) equipment were used to survey the position and elevation of each ERT electrode using Level IV processes and methods described in Rydlund and Densmore (2012) and general techniques described in Bender and Rowe (2015). The RTK surveying was used because it provides higher elevation and position accuracy than hand-held global positioning system units. Elevation accuracy is important for ERT surveys so that the resistivity depth profiles are correlated to a precise landsurface elevation and position. The latitude and longitude data were used to plot the survey lines on a geologic map for interpretation of the bedrock surface. Land-surface elevation data were used with inversion software to provide an accurate representation of the survey area and estimated subsurface depths. Water service lines, electrical boxes, and fuel pipelines also were surveyed with the RTK to identify objects that may interfere with the resistivity survey and areas to avoid during site selection for monitoring wells. The ERT data collected at Fuels Area $\mathrm{C}$ are available in a USGS data release (Medler and others, 2021).

Two of the survey lines (RL2 and RL3) were affected by an equipment error that caused some electrodes to erroneously transmit and receive electrical signals. Data from the electrodes with errors were removed from the survey line dataset, 
Table 2. Site information for 14 monitoring wells and a recovery sump sampled in the study area around Fuels Area C, $2014-18$.

[ID, identification; USGS, U.S. Geological Survey; NAVD 88, North American Vertical Datum of 1988; --, not applicable or available]

\begin{tabular}{|c|c|c|c|c|c|c|c|c|c|c|}
\hline $\begin{array}{c}\text { Map ID } \\
\text { (fig. 1) }\end{array}$ & USGS site ID & USGS name & Site name & $\begin{array}{l}\text { Latitude } \\
\text { (decimal } \\
\text { degrees) }\end{array}$ & $\begin{array}{l}\text { Longitude } \\
\text { (decimal } \\
\text { degrees) }\end{array}$ & $\begin{array}{c}\text { Year of } \\
\text { installation }\end{array}$ & $\begin{array}{l}\text { Altitude } \\
\text { of land } \\
\text { surface, } \\
\text { in meters } \\
\text { above } \\
\text { NAVD } 88\end{array}$ & $\begin{array}{c}\text { Well } \\
\text { depth, in } \\
\text { meters } \\
\text { below } \\
\text { land } \\
\text { surface }\end{array}$ & $\begin{array}{l}\text { Screened } \\
\text { interval, in } \\
\text { meters below } \\
\text { land surface }\end{array}$ & Well completion reports ${ }^{1}$ \\
\hline 1 & 440754103045401 & 2N9E18CAAD1 & MW14-01 & 44.13183 & -103.08183 & 2014 & 964.47 & 10.67 & $3.05-10.67$ & $\begin{array}{c}\text { https://denr.sd.gov/wrimage/ } \\
\text { WellCompletionReports/ } \\
\text { images } 75 \mathrm{k} / 00070887 . p d f\end{array}$ \\
\hline 2 & 440754103045001 & 2N9E18DBBC1 & MW14-02 & 44.13187 & -103.08065 & 2014 & 963.42 & 13.72 & $4.57-13.72$ & $\begin{array}{l}\text { https://denr.sd.gov/wrimage/ } \\
\text { WellCompletionReports/ } \\
\text { images } 75 \mathrm{k} / 00070885 . \mathrm{pdf}\end{array}$ \\
\hline 3 & 440753103045501 & 2N9E18CAAD2 & MW14-03 & 44.13141 & -103.08202 & 2014 & 965.44 & 6.10 & $3.05-6.10$ & $\begin{array}{c}\text { https://denr.sd.gov/wrimage/ } \\
\text { WellCompletionReports/ } \\
\text { images } 75 \mathrm{k} / 00070886 . \mathrm{pdf}\end{array}$ \\
\hline 4 & 440753103045201 & 2N9E18CAAD3 & MW14-04 & 44.13160 & -103.08121 & 2014 & 963.54 & 10.67 & $3.05-10.67$ & $\begin{array}{l}\text { https://denr.sd.gov/wrimage/ } \\
\text { WellCompletionReports/ } \\
\text { images } 75 \mathrm{k} / 00070884 . p d f\end{array}$ \\
\hline 5 & 440751103045301 & 2N9E18CADA1 & MW14-05 & 44.13090 & -103.08152 & 2014 & 964.73 & 4.57 & $1.52-4.57$ & $\begin{array}{c}\text { https://denr.sd.gov/wrimage/ } \\
\text { WellCompletionReports/ } \\
\text { images } 75 \mathrm{k} / 00070883 . p d f\end{array}$ \\
\hline 6 & 440753103045202 & 2N9E18CAAD4 & MW14-06 & 44.13140 & -103.08113 & 2014 & 963.72 & 10.67 & $3.05-10.67$ & $\begin{array}{l}\text { https://denr.sd.gov/wrimage/ } \\
\text { WellCompletionReports/ } \\
\text { images } 75 \mathrm{k} / 00070882 . p d f\end{array}$ \\
\hline 7 & 440753103045001 & 2N9E18DBBC2 & MW14-07 & 44.13142 & -103.08069 & 2014 & 962.41 & 12.19 & $4.57-12.19$ & $\begin{array}{l}\text { https://denr.sd.gov/wrimage/ } \\
\text { WellCompletionReports/ } \\
\text { images } 75 \mathrm{k} / 00070881 . p d f\end{array}$ \\
\hline 8 & 440751103045101 & 2N9E18CADA2 & MW14-08 & 44.13091 & -103.08106 & 2014 & 964.27 & 4.57 & $1.22-4.27$ & $\begin{array}{l}\text { https://denr.sd.gov/wrimage/ } \\
\text { WellCompletionReports/ } \\
\text { images } 75 \mathrm{k} / 00070880 . p d f\end{array}$ \\
\hline 9 & 440752103045001 & 2N9E18DBBC3 & MW14-09 & 44.13133 & -103.08073 & 2014 & 962.49 & 9.14 & $4.57-9.14$ & $\begin{array}{c}\text { https://denr.sd.gov/wrimage/ } \\
\text { WellCompletionReports/ } \\
\text { images } 75 \mathrm{k} / 00070879 . p d f\end{array}$ \\
\hline 10 & 440753103045301 & 2N9E18CAAD5 & MW08C01 & 44.13151 & -103.08149 & 2008 & 964.09 & 6.28 & -- & -- \\
\hline 11 & 440754103045101 & 2N9E18CAAD6 & MW11C02 & 44.13170 & -103.08089 & 2011 & 964.26 & 9.27 & -- & -- \\
\hline 12 & 440754103044801 & 2N9E18DBBC4 & MW2016-01 & 44.13168 & -103.08007 & 2016 & 963.96 & 13.72 & $6.10-13.72$ & $\begin{array}{c}\text { https://denr.sd.gov/wrimage/ } \\
\text { WellCompletionReports/ } \\
\text { images } 75 \mathrm{k} / 00072882 . \mathrm{pdf}\end{array}$ \\
\hline
\end{tabular}


Table 2. Site information for 14 monitoring wells and a recovery sump sampled in the study area around Fuels Area C, 2014-18.-Continued

[ID, identification; USGS, U.S. Geological Survey; NAVD 88, North American Vertical Datum of 1988; --, not applicable or available]

\begin{tabular}{|c|c|c|c|c|c|c|c|c|c|c|}
\hline $\begin{array}{c}\text { Map ID } \\
\text { (fig. 1) }\end{array}$ & USGS site ID & USGS name & Site name & $\begin{array}{l}\text { Latitude } \\
\text { (decimal } \\
\text { degrees) }\end{array}$ & $\begin{array}{l}\text { Longitude } \\
\text { (decimal } \\
\text { degrees) }\end{array}$ & $\begin{array}{c}\text { Year of } \\
\text { installation }\end{array}$ & $\begin{array}{c}\text { Altitude } \\
\text { of land } \\
\text { surface, } \\
\text { in meters } \\
\text { above } \\
\text { NAVD } 88\end{array}$ & $\begin{array}{c}\text { Well } \\
\text { depth, in } \\
\text { meters } \\
\text { below } \\
\text { land } \\
\text { surface }\end{array}$ & $\begin{array}{l}\text { Screened } \\
\text { interval, in } \\
\text { meters below } \\
\text { land surface }\end{array}$ & Well completion reports ${ }^{1}$ \\
\hline 13 & 440752103044801 & 2N9E18DBBC5 & MW2016-02 & 44.13134 & -103.08013 & 2016 & 963.77 & 12.19 & $6.10-12.19$ & $\begin{array}{l}\text { https://denr.sd.gov/wrimage/ } \\
\text { WellCompletionReports/ } \\
\text { images } 75 \mathrm{k} / 00072883 . p d f\end{array}$ \\
\hline 14 & 440747103043801 & 2N9E18DBDC & MW2016-03 & 44.12995 & -103.07713 & 2016 & 950.57 & 7.62 & $3.05-7.62$ & $\begin{array}{l}\text { https://denr.sd.gov/wrimage/ } \\
\text { WellCompletionReports/ } \\
\text { images } 75 \mathrm{k} / 00072884 . p d f\end{array}$ \\
\hline 15 & 440752103045002 & $\begin{array}{l}\text { 2N9E18DBBC4 } \\
\text { EAFB FAC } \\
\text { Sump }\end{array}$ & $\begin{array}{c}\text { Recovery } \\
\text { Sump }\end{array}$ & 44.13133 & -103.08069 & 2015 & 962.36 & -- & -- & -- \\
\hline
\end{tabular}

'South Dakota Department of Environment and Natural Resources (2019). 
which resulted in areas without data to analyze and blank areas in the resistivity profile. Survey lines with electrode errors were clipped into shorter sections before inversion to prevent model convergence errors that would complicate interpretation of the ERT inversion results. Clipping the survey lines affected by electrode errors reduced the lengths of survey lines RL2 and RL3 from 94.5 to $80.5 \mathrm{~m}$ and 144.9 to $113.4 \mathrm{~m}$, respectively.

Two-dimensional ERT models were constructed for each survey line using the EarthImager2D inversion software (Advanced Geosciences Incorporated, 2020b). Land-surface elevation data were assigned to each electrode before inversion to minimize errors from topographic changes. The ERT data were modeled using least-squares smooth-model inversion (Constable and others, 1987; Farquharson and Oldenburg, 1998) because the area surveyed was best approximated as a simple layered model with two or three layers. Smoothmodel inversion reduces differences between measured data from surveys and predicted values from a simple starting model using an iterative process, where successive iterations attempt to reduce the difference between measured data and predicted values by calculating the root mean square (RMS) error. Smooth-model inversion reduces the RMS error until a desired error tolerance is achieved; it does not minimize RMS error because minimizing RMS error increases model roughness and unacceptably departs from the simple starting model (Constable and others, 1987). The maximum number of iterations was set to eight and the final model was chosen based on its representation of the lithology and its relatively low successive RMS improvement. The model derived from the first or second iteration was selected for all four ERT survey lines and each had RMS errors under 5 percent.

\section{Monitoring Well Installation and Site Selection}

The locations of groundwater monitoring wells in the study area around Fuels Area $\mathrm{C}$ were based on a variety of factors including historical groundwater-flow characteristics, results of the ERT survey, proximity to historical spills related to petroleum hydrocarbons, and results of previously collected soil and groundwater samples (Tetra Tech Incorporated, 2008, 2012; Bender and Rowe, 2015). Fourteen groundwater monitoring wells and one recovery sump were used for waterquality sample collection in 2014-18 (table 2). Two existing monitoring wells in Fuels Area C, sites 10 and 11 located near the two USTs (13A and 13B; fig. 1), were selected for sampling because of their proximity to previous spills and their use in previous studies (Tetra Tech Incorporated, 2008, 2012).

In November 2014, nine monitoring wells (sites 1-9) were installed in the study area and in December 2016 three additional wells were installed downgradient from Fuels Area $\mathrm{C}$ (sites 12-14) using the methods described in Bender and Rowe (2015; fig. 1). Well sites 12 and 13 were installed just east of Fuels Area C, and well site 14 was installed farther downgradient just inside the boundary of Prairie Ridge Golf
Course (fig. 1). Monitoring well sites 12, 13, and 14 were used to provide information on plume migration outside of Fuel Area $\mathrm{C}$ and downgradient from a jet fuel spill in June 2015 from UST 13B (BERS-Weston Services JVA, LLC, 2016; fig. 1). Monitoring wells were installed using 2-inch diameter polyvinyl chloride (PVC) pipe. Generally, wells were completed to the approximate depth of the top of the Pierre Shale at each location and well depths varied from $4.57 \mathrm{~m}$ (sites 5 and 8 ) to $13.72 \mathrm{~m}$ below land surface (sites 2 and 12; table 2). The wells were screened from approximately the bottom depth of the well to about 3.0 to $9.1 \mathrm{~m}$ above the bottom of the well, depending on the total well depth (table 2). In November 2015, a recovery sump was installed (BERSWeston Services JVA, LLC, 2016) and also was sampled after installation to provide information on the underdrain water from both USTs.

\section{Generalized Potentiometric-Surface and Groundwater-Flow Determination}

Discrete groundwater levels were collected concurrently with water-quality sampling from November 2014 to June 2018 at the 14 monitoring wells (fig. 1, table 1.1) for use in generating a potentiometric surface in the study area. Groundwater-level measurements were made following USGS protocols described in Cunningham and Schalk (2011) using a calibrated electric tape. After each water-level measurement, the electric tape was disinfected and rinsed using procedures described in U.S. Geological Survey (variously dated). Groundwater-level data collected for this study are available in the USGS National Water Information System (U.S. Geological Survey, 2020) by using the USGS site identification numbers in table 2 .

A potentiometric surface represents the hydraulic head of groundwater, which is the water-table elevation in an unconfined aquifer (Carter and others, 2002). Groundwater levels were converted to hydraulic head values by subtracting the water-level measurements from surveyed elevations of the measuring point from the land surface. Elevations were reported in meters above the North American Vertical Datum of 1988. Potentiometric surfaces can change over time, so to generalize the surface for the period of groundwater monitoring, a mean hydraulic head was computed for each well from the 6 to 11 measurements collected during the sampling period (2014-18).

Potentiometric contours were generated using geographic information system software ArcMap (Esri, 2016) to interpolate the mean hydraulic head values collected in 2014-18. Mean hydraulic head values were interpolated using the "Topo to Raster" tool in ArcMap to generate the potentiometric surface. The Topo to Raster tool creates elevation surfaces using an iterative finite-difference interpolation method that combines the efficiency of local interpolation methods with the surface continuity of global interpolation methods (Esri, 2016). Mean hydraulic head values were contoured using a 
1-m contour interval. Contour lines were manually edited to correct for extremes in high and low water-level elevations and in regions of sparse data within the study area. Potentiometric contours from the potentiometric surface map were used to determine groundwater-flow direction, which was assumed to be perpendicular to the potentiometric contours.

\section{Soil Sample Collection}

During the drilling of the nine monitoring wells installed in November 2014 (sites 1-9) and the three monitoring wells installed in December 2016 (sites 12-14; fig. 1), soil samples were collected as described in Bender and Rowe (2015). Although samples were collected from all nine wells installed in November 2014, the sample collected from site 2 (fig. 1) was damaged during shipment to the laboratory, resulting in 11 total soil samples collected for the study. During drilling, split core intervals were retrieved from each well borehole and visually assessed in a clean area near the drilling site. The assessment included sediment descriptions that were recorded in a lithologic log for each well that were stored and are accessible in South Dakota Department of Environment and Natural Resources (2019). Each retrieved soil core interval was visually inspected, geologically characterized and documented, and field analyzed for hydrocarbons with a RAE Systems MiniRAE 3000 Photoionization Detector (PID) with a $10.6 \mathrm{eV}$ lamp (Bender and Rowe, 2015). The PID was used to determine what intervals of soil cores to sample by measuring the presence of volatile organic compounds (VOCs). Soil samples from each core were collected at the section with the most contamination based on relative PID measurements recorded along the length of the core interval using procedures described in South Dakota Department of Environment and Natural Resources (2003). The soil samples from each well site were taken from the split barrel sampler with stainless steel spoons and immediately placed in 4-ounce glass jars, chilled, and shipped to the laboratory.

Soil and groundwater samples were analyzed for BTEX compounds, $m$ - and $p$-xylene, $o$-xylene, naphthalene, GRO compounds, and DRO compounds by RTI Laboratories, Incorporated in Livonia, Michigan, using methods described in U.S. Environmental Protection Agency (2003, 2006; table 3). GRO compounds are petroleum hydrocarbons in the $\mathrm{C} 6$ to $\mathrm{C} 10$ (6 to 10 hydrocarbon chains) range, including BTEX and naphthalene. DRO compounds can include all extractable organics in the $\mathrm{C} 10$ to $\mathrm{C} 28$ (10 to 28 hydrocarbon chains) range, including components of diesel fuel, jet fuel, mineral spirits, kerosene, and polar nonhydrocarbon compounds (Zemo and others, 2017). Concentrations were sometimes reported to be below the laboratory reporting level (LRL) noted as "less than" values or "nondetections." The LRL is a level set above the method detection level by the laboratory to minimize the risk of reporting a false positive (Oblinger-Childress and others, 1999). Some concentrations were reported as "estimated." Estimated concentrations are concentrations that were greater than the method detection level but below the LRL. In other words, the compound was detected, but there is less certainty of the actual value of the concentration. LRLs for individual constituent samples can be variable because of matrix interferences in the sample. Multiple LRLs were reported for the samples collected for this report and are shown in table 3. For statistical summaries and discussion, the values were recensored to a single level, generally the highest censoring level in the dataset for each constituent (table 3). In a few samples, there was a substantially high LRL reported, and that value was not used in statistical summaries and figures. All soil sample data were stored and are accessible from the USGS National Water Information System database (U.S. Geological Survey, 2020) by using the USGS site identification numbers in table 2.

\section{Groundwater-Quality Sample Collection}

Discrete groundwater-quality samples in the study area were collected from November 2014 to June 2018 at 14 monitoring wells and a recovery sump (fig. 1). Collection and processing of groundwater samples followed USGS protocols described in U.S. Geological Survey (variously dated). Each well was pumped to purge three well-casing volumes of water before groundwater-quality sampling. If a sufficient volume of water remained in the well after purging, then samples were collected using a portable submersible pump with polytetrafluoroethylene (PTFE) tubing. In wells with insufficient volumes of water remaining, defined as less than 1-liter of water, a dedicated PTFE bailer or a PVC bailer for 1-inch diameter well casings were used to collect samples. Each sample was labeled, double bagged, and shipped to RTI Laboratories, Incorporated for chemical analysis. Field measurements also were collected with each sample and included water temperature, specific conductance, dissolved oxygen, $\mathrm{pH}$, and turbidity. Field measurements were recorded during purging using a flow-through chamber and water-quality instrumentation when using a submersible pump during well purging. Aliquots of raw water collected from bailers were used for field measurements when groundwater volumes in wells were too low for pumping and bailer samplers were used (U.S. Geological Survey, variously dated). All equipment was cleaned between sampling sites according to protocols described in U.S. Geological Survey (variously dated). Groundwater-quality samples were analyzed for BTEX compounds, $m$ - and $p$-xylene, $o$-xylene, naphthalene, GRO compounds, and DRO compounds by RTI Laboratories, Incorporated (Livonia, Michigan), using methods described in U.S. Environmental Protection Agency $(2003,2006)$ (table 3). All groundwaterquality sample data were stored and are accessible from the USGS National Water Information System database (U.S. Geological Survey, 2020) by using the USGS site identification numbers in table 2 . 
Table 3. Constituents selected for analyses of soil and groundwater samples collected in the study area around Fuels Area C, $2014-18$.

$[\mathrm{mg} / \mathrm{kg}$, milligram per kilogram; $\mu \mathrm{g} / \mathrm{L}$, microgram per liter; SD, South Dakota; EPA, U.S. Environmental Agency; MCL, maximum contaminant level; --, not applicable]

\begin{tabular}{|c|c|c|c|c|c|c|}
\hline Laboratory method & Compound & $\begin{array}{l}\text { Laboratory } \\
\text { reporting } \\
\text { levels in soil } \\
\text { data, } \\
(\mathrm{mg} / \mathrm{kg})\end{array}$ & $\begin{array}{c}\text { SD Tier } \\
1 \text { action } \\
\text { level, }{ }^{1} \text { soils } \\
\text { (mg/kg) }\end{array}$ & $\begin{array}{c}\text { Reporting levels } \\
\text { in groundwater } \\
\text { data } \\
(\mu \mathrm{g} / \mathrm{L})\end{array}$ & $\begin{array}{l}\text { Recensored } \\
\text { reporting level } \\
\text { used for ground- } \\
\text { water data } \\
(\mu \mathrm{g} / \mathrm{L})\end{array}$ & $\begin{array}{c}\text { EPA MCL, } \\
\text { drinking } \\
\text { water } \\
(\mu \mathrm{g} / \mathrm{L})\end{array}$ \\
\hline $8260 C^{3}$ & Benzene & $0.036-0.094$ & 0.2 & $0.17,1.0$ & 1.0 & 5 \\
\hline $8260 C^{3}$ & Toluene & $0.060-0.094$ & 15 & $0.25,1.0,50$ & 1.0 & 1,000 \\
\hline $8260 C^{3}$ & Xylene, total & $0.18-0.28$ & 300 & $0.22,3.0,15.0$ & 3.0 & 10,000 \\
\hline $8260 C^{3}$ & $m$ - and $p$-Xylene & $0.12-0.19$ & -- & 2.0 & 2.0 & -- \\
\hline $8260 C^{3}$ & $o$-Xylene & $0.060-0.094$ & -- & $1.0,5.0$ & 1.0 & -- \\
\hline $8260 C^{3}$ & Naphthalene & $0.072-0.094$ & 25 & 1.0 & 1.0 & -- \\
\hline $8015 \mathrm{~B}^{4}, 8015 \mathrm{D}^{4}$ & Gasoline-range organics & 3.8 & -- & 100 & 100 & -- \\
\hline
\end{tabular}

${ }^{1}$ State of South Dakota (1996).

${ }^{2}$ U.S. Environmental Protection Agency (2012).

${ }^{3}$ U.S. Environmental Protection Agency (2006).

${ }^{4}$ U.S. Environmental Protection Agency (2003).

\section{Quality Assurance and Quality Control}

Quality-control samples were collected to determine if contamination, matrix effects, and measurement variability affected the chemical analyses of the samples. Field blank, trip blank, and sequential replicate samples were collected during sampling to ensure that data quality acceptability limits were met. Quality-assurance standards were met by using standard procedures for water-quality sample collection described in U.S. Geological Survey (variously dated).

Field blank samples were collected using certified organic-free blank water with the same processing procedures and equipment used for the collection of the environmental samples. Field blank samples were used to check that field cleaning protocols were effective in removing contamination from the equipment. Ten field blanks were collected at monitoring well site 6 and one field blank was collected at monitoring well site 9 (fig. 1) from November 2014 to June 2018, which was one blank per sampling trip (table 4). The field blank collected on October 28, 2015, contained quantifiable concentrations of naphthalene at 3.4 micrograms per liter $(\mu \mathrm{g} / \mathrm{L})$. The groundwater sample collected immediately after the field blank on October 28, 2015, at site 6 did not have detectable concentrations of naphthalene (table 2.1), so the detection of naphthalene in the field blank did not seem to affect the results of the environmental sample. The groundwater sample collected just before the field blank sample on October 28, 2015, at site 5 had a somewhat high concentration of naphthalene $(29 \mu \mathrm{g} / \mathrm{L}$, table 2.1$)$, and residual from the sample may have not been adequately remove from the equipment before the collection of the field blank. GROs were detected in all field blank samples, but concentrations were below the LRL. DROs were detected in 5 of the 10 blanks, but concentrations also were below the LRL (table 4). Groundwater samples collected with the field blanks also had GRO and DRO concentrations similar to concentrations in the field blanks near or below the LRL. The presence of GROs and DROs in both the field blanks and samples below LRL concentrations indicated that sampling equipment may contain GROs and DROs, but in concentrations that were too low to affect the chemical analysis and concentration values measured in the environmental samples that were above the LRL.

Trip blank samples contained certified organic-free blank water and were shipped to the laboratory along with the environmental samples. Trip blank samples were used to check for contamination during the storage and shipping of samples. Samples can become contaminated by diffusion of volatile organics through the sample container septum during shipment and storage. Twenty-six trip blank samples were included with the environmental samples collected and shipped from November 2014 to June 2018 (table 4). The trip blank sample collected from site 11 (fig. 1) on October 29, 2015, had benzene and naphthalene detections at concentrations of 0.4 (estimated) and $1.1 \mu \mathrm{g} / \mathrm{L}$, respectively. No other samples had detectable concentrations of BTEX compounds, $m$ - and $p$-xylene, $o$-xylene, or naphthalene (table 4). Trip blanks were not analyzed for DRO or GRO compounds. The presence of benzene and naphthalene at measurable concentration in the 
Table 4. Results of field blank and trip blank samples collected at sites in the study area around Fuels Area C, 2014-18.

[ID, identification; USGS, U.S. Geological Survey; MM, month; DD, day; YYYY, year; <, less than laboratory reporting level; E, compound present but concentration estimated less than the laboratory reporting level; --, no data]

\begin{tabular}{|c|c|c|c|c|c|c|c|c|c|c|c|c|c|}
\hline \multirow[b]{2}{*}{$\begin{array}{c}\text { Map } \\
\text { ID } \\
\text { (fig. 1) }\end{array}$} & \multirow[b]{2}{*}{ USGS site ID } & \multirow[b]{2}{*}{ Site name } & \multirow[b]{2}{*}{$\begin{array}{c}\text { Sample date } \\
\text { (MM/DD/YYYY) }\end{array}$} & \multirow[b]{2}{*}{$\begin{array}{l}\text { Sample } \\
\text { time }\end{array}$} & \multicolumn{9}{|c|}{ Concentration, in micrograms per liter } \\
\hline & & & & & Benzene & Toluene & Ethylbenzene & $\begin{array}{c}\text { Total } \\
\text { xylenes }\end{array}$ & $\begin{array}{c}m \text { - and } \\
p \text {-Xylene }\end{array}$ & o-Xylene & Naphthalene & $\begin{array}{l}\text { Gasoline- } \\
\text { range } \\
\text { organic } \\
\text { compounds }\end{array}$ & $\begin{array}{c}\text { Diesel- } \\
\text { range } \\
\text { organic } \\
\text { compounds }\end{array}$ \\
\hline \multicolumn{14}{|c|}{ Field blank samples } \\
\hline 9 & 440752103045001 & MW14-09 & $11 / 21 / 2014$ & 1040 & $<1$ & $<1$ & $<1$ & $<3$ & $<2$ & $<1$ & $<1$ & E45 & $<220$ \\
\hline 6 & 440753103045202 & MW14-06 & $06 / 16 / 2015$ & 1235 & $<1.0$ & E0.2 & E0.3 & E1.5 & E1.5 & $<1.0$ & $<1.0$ & E39 & E54 \\
\hline 6 & 440753103045202 & MW14-06 & $10 / 28 / 2015$ & 0945 & $<1.0$ & $<1.0$ & $<1.0$ & $<3.0$ & $<2.0$ & $<1.0$ & 3.4 & E21 & E50 \\
\hline 6 & 440753103045202 & MW14-06 & $03 / 22 / 2016$ & 0902 & $<1.0$ & $<1.0$ & $<1.0$ & $<3.0$ & $<2.0$ & $<1.0$ & $<1.0$ & E27 & E26 \\
\hline 6 & 440753103045202 & MW14-06 & $06 / 08 / 2016$ & 0920 & $<1.0$ & $<1.0$ & $<1.0$ & $<3.0$ & $<2.0$ & $<1.0$ & $<1.0$ & E21 & E35 \\
\hline 6 & 440753103045202 & MW14-06 & $04 / 13 / 2017$ & 0905 & $<1.0$ & $<1.0$ & $<1.0$ & $<3.0$ & $<2.0$ & $<1.0$ & $<1.0$ & E51 & $<200$ \\
\hline 6 & 440753103045202 & MW14-06 & $06 / 28 / 2017$ & 1105 & $<1.0$ & $<1.0$ & $<1.0$ & $<3.0$ & $<2.0$ & $<1.0$ & $<1.0$ & E82 & $<200$ \\
\hline 6 & 440753103045202 & MW14-06 & $09 / 13 / 2017$ & 1405 & $<1.0$ & $<1.0$ & $<1.0$ & $<3.0$ & $<2.0$ & $<1.0$ & $<1.0$ & E91 & E100 \\
\hline 6 & 440753103045202 & MW14-06 & $12 / 13 / 2017$ & 1105 & $<1.0$ & $<1.0$ & $<1.0$ & $<3.0$ & $<2.0$ & $<1.0$ & $<1.0$ & E83 & $<200$ \\
\hline 6 & 440753103045202 & MW14-06 & $04 / 10 / 2018$ & 1005 & $<1.0$ & $<1.0$ & $<1.0$ & $<3.0$ & $<2.0$ & $<1.0$ & $<1.0$ & E86 & $<200$ \\
\hline 6 & 440753103045202 & MW14-06 & $06 / 22 / 2018$ & 1105 & $<0.2$ & $<0.2$ & $<0.2$ & $<0.2$ & -- & -- & $<1.0$ & E26 & $<200$ \\
\hline \multicolumn{14}{|c|}{ Trip blank samples } \\
\hline 7 & 440753103045001 & MW14-07 & $11 / 21 / 2014$ & 1200 & $<1.0$ & $<1.0$ & $<1.0$ & $<3.0$ & $<2.0$ & $<1.0$ & $<1.0$ & -- & -- \\
\hline 7 & 440753103045001 & MW14-07 & $06 / 17 / 2015$ & 0952 & $<1.0$ & $<1.0$ & $<1.0$ & $<3.0$ & $<2.0$ & $<1.0$ & $<1.0$ & -- & -- \\
\hline 10 & 440753103045301 & MW08C01 & $06 / 18 / 2015$ & 1102 & $<1.0$ & $<1.0$ & $<1.0$ & $<3.0$ & $<2.0$ & $<1.0$ & $<1.0$ & -- & -- \\
\hline 2 & 440754103045001 & MW14-02 & $10 / 27 / 2015$ & 1535 & $<1.0$ & $<1.0$ & $<1.0$ & $<3.0$ & $<2.0$ & $<1.0$ & $<1.0$ & -- & -- \\
\hline 10 & 440753103045301 & MW08C01 & $10 / 28 / 2015$ & 1435 & $<1.0$ & $<1.0$ & $<1.0$ & $<3.0$ & $<2.0$ & $<1.0$ & $<1.0$ & -- & -- \\
\hline 11 & 440754103045101 & MW11C02 & $10 / 29 / 2015$ & 1305 & E0.4 & $<1.0$ & $<1.0$ & $<3.0$ & $<2.0$ & $<1.0$ & 1.1 & -- & -- \\
\hline 10 & 440753103045301 & MW08C01 & $03 / 22 / 2016$ & 1305 & $<1.0$ & $<1.0$ & $<1.0$ & $<3.0$ & $<2.0$ & $<1.0$ & $<1.0$ & -- & -- \\
\hline 2 & 440754103045001 & MW14-02 & $03 / 23 / 2016$ & 0902 & $<1.0$ & $<1.0$ & $<1.0$ & $<3.0$ & $<2.0$ & $<1.0$ & $<1.0$ & -- & -- \\
\hline 7 & 440753103045001 & MW14-07 & 06/07/2016 & 1402 & $<1.0$ & $<1.0$ & $<1.0$ & $<3.0$ & $<2.0$ & $<1.0$ & $<1.0$ & -- & -- \\
\hline 10 & 440753103045301 & MW08C01 & 06/09/2016 & 1102 & $<1.0$ & $<1.0$ & $<1.0$ & $<3.0$ & $<2.0$ & $<1.0$ & $<1.0$ & -- & -- \\
\hline 2 & 440754103045001 & MW14-02 & $04 / 12 / 2017$ & 1205 & $<1.0$ & $<1.0$ & $<1.0$ & $<3.0$ & $<2.0$ & $<1.0$ & $<1.0$ & -- & -- \\
\hline 11 & 440754103045101 & MW11C02 & $04 / 13 / 2017$ & 1405 & $<1.0$ & $<1.0$ & $<1.0$ & $<3.0$ & $<2.0$ & $<1.0$ & $<1.0$ & -- & -- \\
\hline 14 & 440747103043801 & MW2016-03 & $04 / 17 / 2017$ & 1535 & $<1.0$ & $<1.0$ & $<1.0$ & $<3.0$ & $<2.0$ & $<1.0$ & $<1.0$ & -- & -- \\
\hline 7 & 440753103045001 & MW14-07 & $06 / 27 / 2017$ & 1335 & $<1.0$ & $<1.0$ & $<1.0$ & $<3.0$ & $<2.0$ & $<1.0$ & $<1.0$ & -- & -- \\
\hline 2 & 440754103045001 & MW14-02 & $06 / 29 / 2017$ & 1200 & $<1.0$ & $<1.0$ & $<1.0$ & $<3.0$ & $<2.0$ & $<1.0$ & $<1.0$ & -- & -- \\
\hline
\end{tabular}


Table 4. Results of field blank and trip blank samples collected at sites in the study area around Fuels Area C, 2014-18.-Continued

[ID, identification; USGS, U.S. Geological Survey; MM, month; DD, day; YYYY, year; <, less than laboratory reporting level; E, compound present but concentration estimated less than the laboratory reporting level; --, no data]

\begin{tabular}{|c|c|c|c|c|c|c|c|c|c|c|c|c|c|}
\hline \multirow[b]{2}{*}{$\begin{array}{c}\text { Map } \\
\text { ID } \\
\text { (fig. 1) }\end{array}$} & \multirow[b]{2}{*}{ USGS site ID } & \multirow[b]{2}{*}{ Site name } & \multirow[b]{2}{*}{$\begin{array}{c}\text { Sample date } \\
\text { (MM/DD/YYYY) }\end{array}$} & \multirow[b]{2}{*}{$\begin{array}{l}\text { Sample } \\
\text { time }\end{array}$} & \multicolumn{9}{|c|}{ Concentration, in micrograms per liter } \\
\hline & & & & & Benzene & Toluene & Ethylbenzene & $\begin{array}{c}\text { Total } \\
\text { xylenes }\end{array}$ & $\begin{array}{c}m \text { - and } \\
p \text {-Xylene }\end{array}$ & o-Xylene & Naphthalene & $\begin{array}{l}\text { Gasoline- } \\
\text { range } \\
\text { organic } \\
\text { compounds }\end{array}$ & $\begin{array}{c}\text { Diesel- } \\
\text { range } \\
\text { organic } \\
\text { compounds }\end{array}$ \\
\hline \multicolumn{14}{|c|}{ Trip blank samples_-Continued } \\
\hline 11 & 440754103045101 & MW11C02 & $06 / 29 / 2017$ & 1605 & $<1.0$ & $<1.0$ & $<1.0$ & $<3.0$ & $<2.0$ & $<1.0$ & $<1.0$ & -- & -- \\
\hline 14 & 440747103043801 & MW2016-03 & $06 / 30 / 2017$ & 1005 & $<1.0$ & $<1.0$ & $<1.0$ & $<3.0$ & $<2.0$ & $<1.0$ & $<1.0$ & -- & -- \\
\hline 2 & 440754103045001 & MW14-02 & 09/14/2017 & 1205 & $<1.0$ & $<1.0$ & $<1.0$ & $<3.0$ & $<2.0$ & $<1.0$ & $<1.0$ & -- & -- \\
\hline 14 & 440747103043801 & MW2016-03 & 09/20/2017 & 0930 & $<1.0$ & $<1.0$ & $<1.0$ & $<3.0$ & $<2.0$ & $<1.0$ & $<1.0$ & -- & -- \\
\hline 11 & 440754103045101 & MW11C02 & $12 / 11 / 2017$ & 1435 & $<1.0$ & $<1.0$ & $<1.0$ & $<3.0$ & $<2.0$ & $<1.0$ & $<1.0$ & -- & -- \\
\hline 2 & 440754103045001 & MW14-02 & $12 / 12 / 2017$ & 1405 & $<1.0$ & $<1.0$ & $<1.0$ & $<3.0$ & $<2.0$ & $<1.0$ & $<1.0$ & -- & -- \\
\hline 7 & 440753103045001 & MW14-07 & 04/09/2018 & 1400 & $<1.0$ & $<1.0$ & $<1.0$ & $<3.0$ & $<2.0$ & $<1.0$ & $<1.0$ & -- & -- \\
\hline 2 & 440754103045001 & MW14-02 & $04 / 10 / 2018$ & 1235 & $<1.0$ & $<1.0$ & $<1.0$ & $<3.0$ & $<2.0$ & $<1.0$ & $<1.0$ & -- & -- \\
\hline 2 & 440754103045001 & MW14-02 & $06 / 21 / 2018$ & 1305 & $<0.2$ & $<0.2$ & $<0.2$ & $<0.2$ & -- & -- & $<1.0$ & -- & -- \\
\hline 10 & 440753103045301 & MW08C01 & $06 / 25 / 2018$ & 1235 & $<0.2$ & $<0.2$ & $<0.2$ & $<0.2$ & -- & -- & $<1.0$ & -- & -- \\
\hline 14 & 440747103043801 & MW2016-03 & $06 / 28 / 2018$ & 1300 & $<0.2$ & $<0.2$ & $<0.2$ & $<0.2$ & -- & -- & $<1.0$ & -- & -- \\
\hline
\end{tabular}


samples from October 29, 2015, likely did not affect the results of the environmental samples because the associated samples that were shipped with the trip blank either had no detections of benzene and naphthalene or concentrations were much higher than those found in the trip blank.

Replicate samples provide information on the variability in the sample collection, processing, shipment, and analysis of the samples. Eleven replicate samples were collected from 2014 to 2018 at site 1 (table 2.1). The relative percent difference (RPD) provides a measure of the precision of the chemical analyses between two samples. The RPD was calculated as the absolute difference in concentration from the sample pairs divided by mean concentration multiplied by 100 for the environmental and replicate pairs with detections in both samples (table 5). Replicate samples for benzene, toluene, $m$ - and $p$-xylene, and naphthalene had no detectable concentrations; therefore, the RPDs were not calculated for those 11 sample pairs. Several replicate paired samples for the other constituents also did not have detectable concentrations and the relative percent difference also was not calculated for those samples. One replicate collected on November 21, 2014, had substantial differences in concentrations for all constituents by up to an order of magnitude difference, indicating that the sample may have been mislabeled or that the results were transposed with samples from another site (table 2.1). Because of the discrepancy, the sample was removed from the mean RPD calculation (table 5). The mean RPD for ethylbenzene (2 samples), total xylenes (1 sample), naphthalene (1 sample), GRO compounds (9 samples), and DRO compounds (10 samples) were 23.1, $19,5.1,9.3$, and 37.3 percent, respectively (table 5). Ideally, RPD values should be less than 20 percent, indicating that the variability in ethylbenzene and DRO concentrations were not as well reproducible as the other constituents either in the collection, processing, or laboratory analysis of the samples.

\section{Hydrogeologic Assessment of Fuels Area C}

Understanding the hydrogeology of the study area around Fuels Area $\mathrm{C}$ is important for understanding the presence and movement of petroleum hydrocarbons in the subsurface of the area. Four ERT surveys were used to estimate the depth to the Pierre Shale (bedrock) in the study area. The depth to bedrock data provides information on potential pathways for groundwater flow. Additionally, a groundwater potentiometric surface map was created with groundwater levels collected between November 2014 and June 2018. The potentiometric map is useful for estimating groundwater-flow directions in the study area.

\section{Subsurface Characterization}

The subsurface study area around Fuels Area $\mathrm{C}$ was characterized using ERT inversion results from four ERT survey lines and nearby wells that provided an estimated depth to the underlying Pierre Shale (fig. 2). Determining the depth to the top of the Pierre Shale was important because variations in the bedrock surface may affect groundwater-flow paths. Erosion from surface exposure and former drainage areas may have created topographically low areas in the Pierre Shale that facilitate groundwater flow. The topographically low areas in the Pierre Shale may not correspond to topographically low areas in the land surface, which explains groundwater-flow paths that do not correspond with surface water drainages or the topography of the land surface. Understanding the flow path dynamics of alluvial materials overlying the Pierre Shale could assist with predicting groundwater-flow directions and contamination movement in the subsurface around Fuels Area C.

Table 5. Relative percent differences of concentrations between replicate and environmental sample pairs for samples collected at monitoring well site 1 within Fuels Area C, 2014-18.

[Calculation of relative percent difference is $\left|\left(x_{1}-x_{2}\right) /\left(x_{1}+x_{2}\right) / 2\right|^{*} 100$, where $x_{1}$ is the concentration in the environmental sample and $x_{2}$ is the concentration in the sequential replicate sample; --, no data]

\begin{tabular}{lcc}
\hline \multicolumn{1}{c}{ Constituent } & $\begin{array}{c}\text { Total number of sample pairs (number used } \\
\text { in calculation) }\end{array}$ & Mean relative percent difference \\
\hline Benzene & $11(0)$ & -- \\
Toluene & $11(0)$ & -- \\
Ethylbenzene & $11(2)$ & 23.1 \\
Total xylenes & $11(1)$ & 19 \\
$m$ - \& p-Xylene & $11(0)$ & -- \\
Naphthalene & $11(1)$ & 5.1 \\
Gasoline-range organic compounds & $11(9)$ & 9.3 \\
Diesel-range organic compounds & $11(10)$ & 37.3 \\
\hline
\end{tabular}

${ }^{1}$ Only samples with measurable concentrations were used in the calculation of percent difference. 


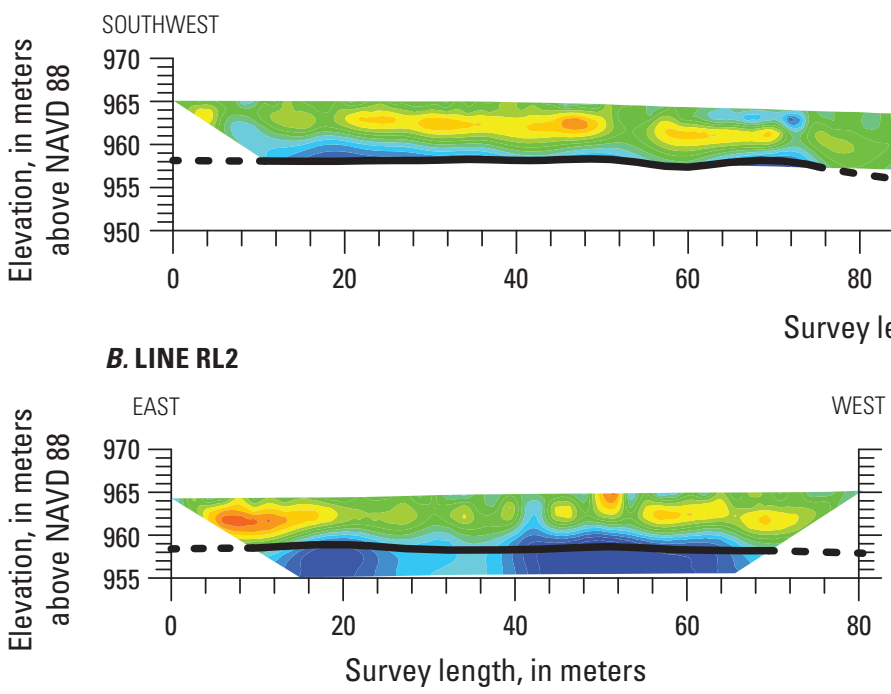

\section{LINE RL3}

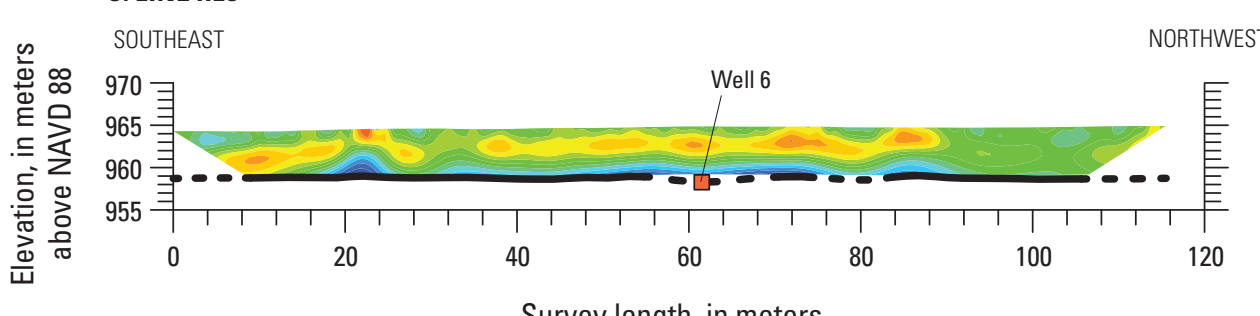

Survey length, in meters

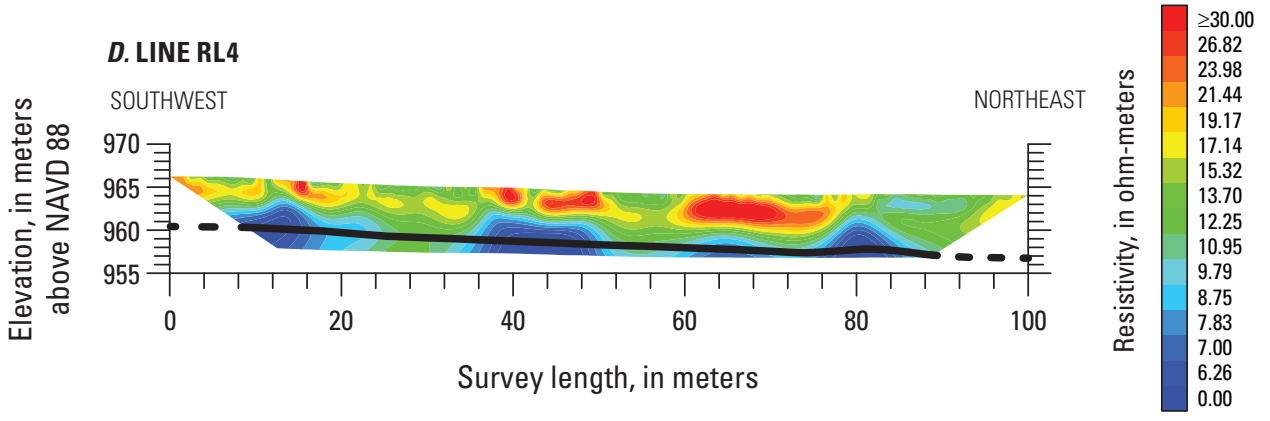
Base modified from U.S. Department of Agriculture
National Agricultural Imagery Program, South Dakota, 2018
Universal Transverse Mercator projection, zone 13 North North American Datum of 1983

\section{EXPLANATION}

Geologic units from Redden and DeWitt (2009)

Qt Quaternary terrace gravel and alluvial-fan deposit

$\mathrm{Kp}$ Cretaceous Pierre Shale

- - Delineated Pierre Shale contact from passive seismic and electrical resistivity. Dashed where contact is approximated

6 Electrical resistivity survey lines

- Monitoring well, with map identification number (see table 2)

Well $2 \square \quad$ Top of the Pierre Shale from monitoring well lithologic log

Vertical and horizontal scale No vertical exaggeration $0 \quad 10 \quad 20$ METERS

Figure 2. Resistivity inversion results for electrical resistivity survey lines in the study area around Fuels Area C. $A, \mathrm{RL} 1 . B, \mathrm{RL}$. $C, \mathrm{RL} 3 . D, \mathrm{RL} 4$. [NAVD 88, North American Vertical Datum of 1988] 
The depth to the top of the Pierre Shale from the land surface along the four ERT survey lines ranged from about 5.4 to $8.7 \mathrm{~m}$ (17.8 to $28.5 \mathrm{ft}$ ). The depth to the Pierre Shale for RL1 (fig. $2 A$ ) ranged from about 5.9 to $8.7 \mathrm{~m}$ (19.3 to $28.5 \mathrm{ft}$ ). The three wells proximal to RL1 (fig. 2) were used with ERT inversion results to delineate the top of the Pierre Shale (fig. $2 A$ ). A topographically low area in the Pierre Shale was observed between 80 and $120 \mathrm{~m}$ along RL1, which also was the lowest Pierre Shale elevation observed among all four ERT survey lines; the topographically low area in the Pierre Shale did not correlate with a low area in the topography of the land surface. The land surface along RL1 varied by about $1.5 \mathrm{~m}(5 \mathrm{ft})$ and decreased in elevation from southwest to northeast (fig. $2 A$ ). The resistivity of unconsolidated materials overlying the Pierre Shale for RL1 ranged from about 0 to 26 ohm-meters, which was expected because lithologic logs from proximal wells reported geologic materials that were mostly clay with minor amounts of sand and gravel. The Pierre Shale was differentiated from the clay deposits by its generally consistent resistivity with values between 5 and 10 ohm-meters.

The depth to the Pierre Shale for RL2 (fig. $2 B$ ) ranged from about 5.6 to $7.3 \mathrm{~m}$ (18.3 to $23.9 \mathrm{ft}$ ). The top of the Pierre Shale was delineated for RL2 using only ERT inversion results (fig. 2B) because no wells were near the survey line. The Pierre Shale along RL2 was somewhat flat and without discernable topographically high or low areas. The land surface along RL2 varied by only about $0.84 \mathrm{~m}(2.8 \mathrm{ft})$ and decreased in elevation from west to east. The resistivity of unconsolidated materials overlying the Pierre Shale for RL2 ranged from about 5 to 26 ohm-meters. No wells with lithologic logs were near RL2, but the range of resistivity values was similar to RL1, which indicated unconsolidated geologic materials along RL2 also were mostly clay with minor amounts of sand and gravel.

The depth to the Pierre Shale for RL3 (fig. 2C) ranged from about 5.4 to $6.6 \mathrm{~m}$ (17.8 to $21.5 \mathrm{ft}$ ). A single well proximal to RL3 was used with ERT inversion results to delineate the top of the Pierre Shale (fig. 2C). The Pierre Shale showed a slight topographic low between 57 and $65 \mathrm{~m}$ for RL3 but was otherwise nearly flat (fig. 2C). The slight topographic low in the Pierre Shale did not correlate with a low area in the topography of the land surface. The land surface along RL3 varied by only about $0.74 \mathrm{~m}(2.4 \mathrm{ft})$ and increased in elevation from southeast to northwest (fig. 2C). The estimated elevation of the top of the Pierre Shale at the intersection of survey lines RL1 and RL3 was nearly the same and differed by only $0.2 \mathrm{~m}(0.66 \mathrm{ft})$ (figs. $2 A$ and $2 C$ ). The resistivity of unconsolidated materials overlying the Pierre Shale for RL3 ranged from about 6 to 27 ohm-meters. The lithologic log of the single well along RL3 reported mostly clay with minor amounts of sand and gravel.

The depth to the Pierre Shale for RL4 (fig. 2D) ranged from about 5.6 to $7.3 \mathrm{~m}$ (18.3 to $23.9 \mathrm{ft}$ ). The top of the Pierre Shale was delineated for RL4 using only ERT inversion results (fig. 2D) because no wells were near the survey line. The elevation of the top of the Pierre Shale along RL4 decreased from southwest to northeast and followed land-surface topography (fig. 2D). The land surface along RL4 varied by about
$2.2 \mathrm{~m}(7.2 \mathrm{ft})$ and decreased in elevation from southwest to northeast (fig. 2D). The elevation difference of the Pierre Shale was about $0.2 \mathrm{~m}(0.66 \mathrm{ft})$ at the intersection of RL4 with RL3 and RL1 (fig. 2). The resistivity of unconsolidated materials overlying the Pierre Shale for RL4 ranged from about 4.5 to $41 \mathrm{ohm}-$ meters. The range of resistivity values along RL4 was the greatest among all four ERT survey lines, which indicated unconsolidated materials along RL4 also were mostly clay but could have greater sand and gravel content than materials underlying the other ERT survey lines.

\section{Groundwater Flow}

A generalized potentiometric-surface map was used to characterize groundwater-flow directions in the study area (fig. 3). Groundwater-flow directions were assumed to be perpendicular to the potentiometric contours (fig. 3); however, that assumption is invalid if the anisotropic permeability of the alluvial aquifer varies considerably (Redden and DeWitt, 2009). The potentiometric contours indicate that groundwater flows from west to east or southwest to southeast in the area near Fuels Area C (fig. 3). The groundwater-flow pattern is similar to the flow directions mapped by previous investigations, which concluded that the groundwater in the study area originates from recharge sources in the alluvial aquifer at higher elevations of EAFB, initially flows southeast, and then flows to the east (Tetra Tech Incorporated, 2008, 2012). The generalized potentiometric-surface map constructed for this report was compared to a potentiometric-surface map of the alluvial aquifer by Tetra Tech Incorporated (2008, 2012). A visual comparison indicated that although potentiometric contours and flow directions were generally similar, there were slight differences in some areas, likely because more water-level data at more sites were available for construction of the potentiometric surface for this report (table 6) than were available for the Tetra Tech Incorporated report $(2008,2012)$.

The groundwater data and data interpretation used to construct the generalized potentiometric-surface map have limitations because the potentiometric surface is a numerical representation of a natural system over time. The data used to construct the map included multiple water-level measurements recorded just before water-quality sampling. Some water-level values could be biased low because levels in the wells may not have fully recovered from previous well purging and sampling. Additionally, water-level measurements were from different years (2014-18), and different times of the year; therefore, the potentiometric surface is general and not specific. In some cases, inferred potentiometric contours may pass through unsaturated zones of the alluvial aquifer because of interpolation or data gaps (Anderson and others, 2019). Data interpretation also had limitations primarily because potentiometric contours are nonunique numeric approximations of a dynamic and complex system, and contour interpretations are affected by the availability and location of groundwater-level measurements and the interpolation method. 


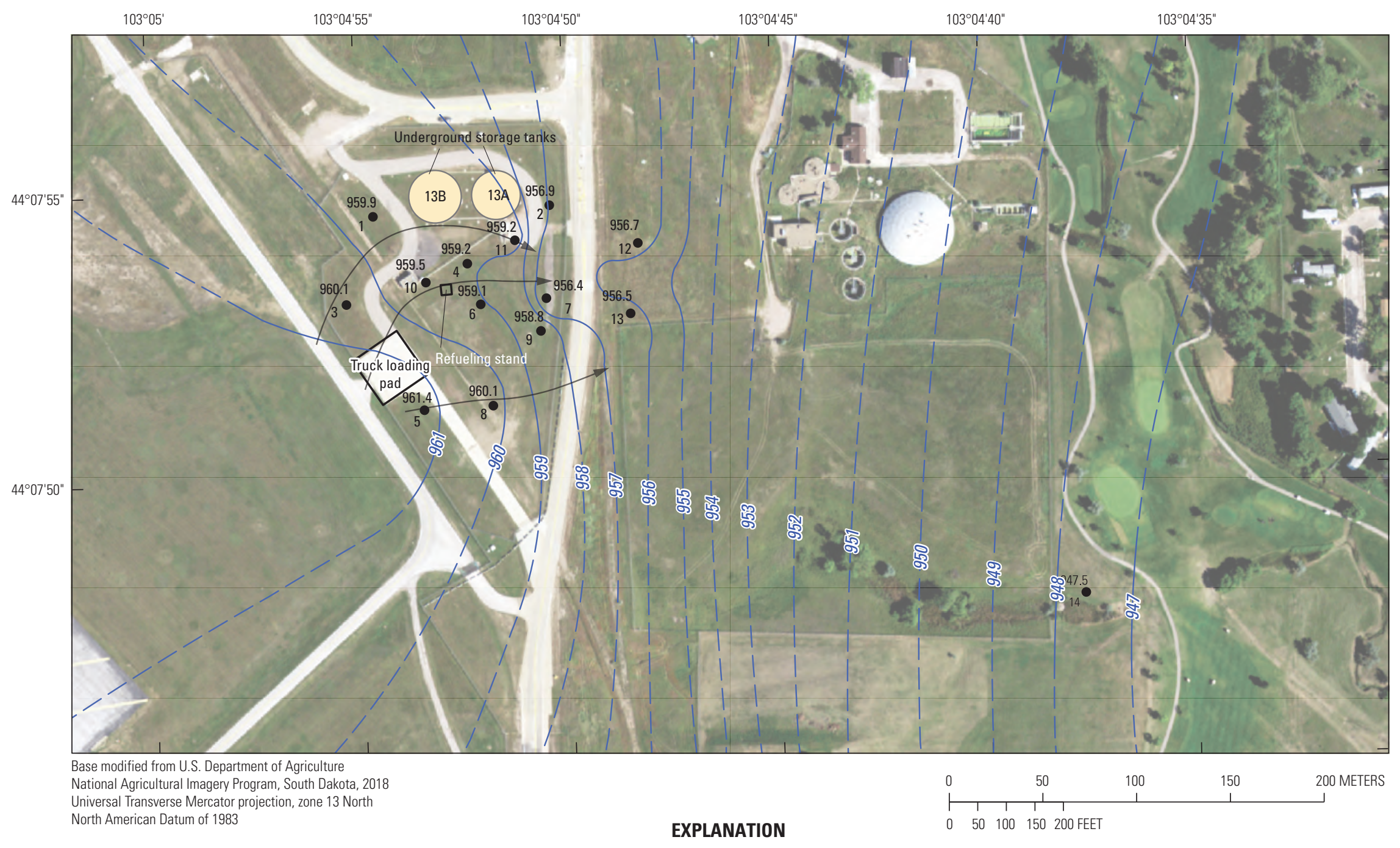
— 948 — Potentiometric contour-Shows mean observed elevation at which water level would have stood in a tightly cased well, in meters.
Dashed where approximately located. Contour interval 1 meter.
Datum is North American Vertical Datum of 1988 (NAVD 88 )

961.4 Groundwater monitoring wells-Numbers above are

mean (2014-18) hydraulic head, in meters above NAVD 88 datum. Numbers below are map idenfication number (see table 2)

Figure 3. Generalized potentiometric surface estimated for the alluvial aquifer in the study around Fuels Area C, 2014-18. 
Table 6. Mean water-level and hydraulic head data used to construct a generalized potentiometric-surface map of the alluvial aquifer in the study area around Fuels Area C, 2014-18.

[All water-level data for these sites are available from the U.S. Geological Survey National Water Information System database (U.S. Geological Survey, 2020); ID, identification; USGS, U.S. Geological Survey; NAVD 88, North American Vertical Datum of 1988]

\begin{tabular}{|c|c|c|c|c|c|c|c|}
\hline $\begin{array}{c}\text { Map ID } \\
\text { (fig. 1) }\end{array}$ & USGS site ID & Site name & $\begin{array}{c}\text { Land-surface } \\
\text { elevation, in } \\
\text { meters above } \\
\text { NAVD } 88\end{array}$ & $\begin{array}{c}\text { Number of } \\
\text { water-level } \\
\text { measurements } \\
\text { used for mean } \\
\text { water level }\end{array}$ & $\begin{array}{l}\text { Period of record } \\
\text { for multiple } \\
\text { water-level } \\
\text { measurements }\end{array}$ & $\begin{array}{c}\text { Mean } \\
\text { water-level } \\
\text { depth below } \\
\text { land surface } \\
\text { (meters) }\end{array}$ & $\begin{array}{c}\text { Mean } \\
\text { hydraulic-head } \\
\text { elevation, in } \\
\text { meters above } \\
\text { NAVD } 88\end{array}$ \\
\hline 1 & 440754103045401 & MW14-01 & 964.47 & 11 & $\begin{array}{l}\text { Nov. } 2014- \\
\text { June } 2018\end{array}$ & 4.61 & 959.86 \\
\hline 3 & 440753103045501 & MW14-03 & 965.44 & 11 & $\begin{array}{l}\text { Nov. } 2014- \\
\text { June } 2018\end{array}$ & 5.30 & 960.13 \\
\hline 4 & 440753103045201 & MW14-04 & 963.54 & 11 & $\begin{array}{l}\text { Nov. } 2014- \\
\text { June } 2018\end{array}$ & 4.38 & 959.16 \\
\hline 5 & 440751103045301 & MW14-05 & 964.73 & 10 & $\begin{array}{l}\text { Nov. } 201- \\
\text { June } 2018\end{array}$ & 3.30 & 961.43 \\
\hline 7 & 440753103045001 & MW14-07 & 962.41 & 11 & $\begin{array}{l}\text { Nov. } 2014- \\
\text { June } 2018\end{array}$ & 5.98 & 956.43 \\
\hline 8 & 440751103045101 & MW14-08 & 964.27 & 7 & $\begin{array}{l}\text { Nov. } 2014- \\
\text { June } 2018\end{array}$ & 4.21 & 960.06 \\
\hline 9 & 440752103045001 & MW14-09 & 962.49 & 11 & $\begin{array}{l}\text { Nov. } 2014- \\
\text { June } 2018\end{array}$ & 3.70 & 958.79 \\
\hline 10 & 440753103045301 & MW08C01 & 964.09 & 10 & $\begin{array}{l}\text { June } 2015- \\
\text { June } 2018\end{array}$ & 4.57 & 959.52 \\
\hline 11 & 440754103045101 & MW11C02 & 964.26 & 10 & $\begin{array}{l}\text { June } 2015- \\
\text { June } 2018\end{array}$ & 5.06 & 959.21 \\
\hline
\end{tabular}




\section{Assessment of Petroleum Hydrocarbons within and near Fuels Area C}

Soil and groundwater samples were collected at selected locations from 2014 to 2018 to better understand the presence and movement of petroleum hydrocarbons in the study area around Fuels Area C. Soil samples were collected at eight wells during installation in 2014 and three wells during installation in 2016. Groundwater samples were collected from 14 wells and a recovery sump in the study area from 2014 to 2018.

\section{Petroleum Hydrocarbons in Soils}

Several petroleum hydrocarbon compounds were detected, but at concentrations below action levels, in the soil samples collected in 2014 and 2016 (table 7). Petroleum hydrocarbon concentrations measured in the soil were compared against Tier 1 action levels established by the State of South Dakota for petroleum contaminated soils (State of South Dakota, 1996; table 3). Tier 1 action levels apply only to soils and are defined as concentrations for that constituent present in the soil where leaching to the groundwater may pose a risk to human health and the environment. Benzene and toluene were not detected in any of the soil samples from the 11 monitoring well sites (table 7). Ethylbenzene was detected at well sites 1 and 7 with concentrations of 3.0 and 0.28 milligram per kilogram ( $\mathrm{mg} / \mathrm{kg})$, respectively; both were below the Tier 1 action level of $10 \mathrm{mg} / \mathrm{kg}$. Total xylenes, $m$ - and $p$-xylenes, and $o$-xylenes also were detected at sites 1 and 7 . Total xylenes at sites 1 and 7 had concentrations of 1.1 and 0.18 (estimated) $\mathrm{mg} / \mathrm{kg}$, respectively, and both were two orders of magnitude below the Tier 1 action level of $300 \mathrm{mg} / \mathrm{kg}$ (tables 3 and 7). Naphthalene was detected in samples from five well sites (sites 1, 5, 7, 8, and, 9), but concentrations also were less than the Tier 1 action level of $25 \mathrm{mg} / \mathrm{kg}$ (tables 3 and 7).

GRO compounds were detected in all soil samples collected during the installation of 11 groundwater monitoring wells in 2014 and 2016 (table 7). DRO compounds were detected in 9 out of the 11 soil samples collected at the 11 monitoring wells. South Dakota has not established Tier 1 action levels for GROs and DROs, but a Tier 2 assessment level of $500 \mathrm{mg} / \mathrm{kg}$ for total petroleum hydrocarbons (TPHs) is used in this report as a reference (State of South Dakota, 2004). GRO and DRO measure components of TPHs. GRO compound concentrations exceeded the Tier 2 assessment level for TPHs in soil samples from site $1(5,200 \mathrm{mg} / \mathrm{kg})$, site $5(580 \mathrm{mg} / \mathrm{kg})$, and site $9(1,800 \mathrm{mg} / \mathrm{kg})$; the remaining sites had concentrations below the Tier 2 assessment level for TPHs. The highest concentrations of DRO compounds in soil samples were from site $1(3,600 \mathrm{mg} / \mathrm{kg})$, site 5 (440 mg/ $\mathrm{kg})$, and site $14(330 \mathrm{mg} / \mathrm{kg})$, and only the sample from site 1 exceeded the Tier 2 assessment level for TPH (table 7).

\section{Petroleum Hydrocarbons in Groundwater}

Petroleum hydrocarbon concentrations were measured in groundwater samples collected from 14 groundwater monitoring wells and 1 recovery sump between 2014 and 2018 in the study area around Fuels Area C (table 8). Eleven total samples were collected during the period at most of the wells installed during or before 2014 (sites 1, 2, 4, 6, 7, 9, and 10), and a total of six samples were collected at wells installed in 2016 (sites 12-14; table 8). Sites 3, 5, and 8 had fewer samples because the wells did not contain sufficient volumes of water at the time of sample collection (table 2.1). Only one sample was collected at site 8 because either the well was dry or had insufficient water for sampling during 2014-18. Samples were analyzed for petroleum hydrocarbon compounds including BTEX compounds, naphthalene, GRO compounds, and DRO compounds.

\section{Benzene, Toluene, Ethylbenzene, Xylene, and Naphthalene}

Benzene, toluene, ethylbenzene, and xylene (BTEX) and naphthalene are VOCs that typically are present in petroleum products such as diesel fuel and gasoline. BTEX compounds are light, volatile, mobile, and water soluble (Mitra and Roy, 2011). When exposed to oxygen and sunlight, most BTEX compounds break down quickly. Organic compounds like BTEX tend to be more persistent in groundwater than in surface water and readily partition into equilibrium between water and soil (Mitra and Roy, 2011). Exposures to high levels of BTEX compounds can be associated with central nervous system depression, skin and sensory irritation, and negative effects on the respiratory system. These compounds also could harm kidney, liver, and blood systems (U.S. Environmental Protection Agency, 2013). Benzene is known to cause cancer, based on evidence in people and laboratory animals (U.S. Environmental Protection Agency, 2016). The U.S. Environmental Protection Agency (EPA) has established drinking water maximum contaminant levels (MCLs) for BTEX (U.S. Environmental Protection Agency, 2012; table 3).

BTEX compounds were detected in at least one sample collected from 10 of the 15 sites sampled in the study area from 2014 to 2018 (table 8). Samples from monitoring well sites $2,3,6,8$, and 9 did not have any quantifiable concentrations of BTEX compounds (table 8, fig. 4). Multiple BTEX compounds were detected consistently in samples collected from sites 10 and 11 (fig. 4). Benzene was detected consistently in samples from site 5 (9 out of 10 samples) although no other BTEX compounds were detected at the site (fig. 4A). Site 1 had detections of ethylbenzene and total xylenes only in samples collected in 2014 and 2015 but none in samples collected at the site in subsequent years (table 2.1). At sites 4 and 7, various BTEX compounds were detected only in one sample collected in November 2014 and none in subsequent samples (table 2.1). Few BTEX compounds were detected at 
Table 7. Summary of petroleum hydrocarbon compound concentrations in soil samples collected at 11 sites in 2014 and 2016 in the study area around Fuels Area C.

[ID, identification; MM, month; DD, day; YYYY, year; GRO, gasoline-range organic; DRO, diesel-range organic; NA, not applicable; >, greater than; <, less than laboratory reporting level; E, compound present but concentration estimated less than the laboratory reporting level]

\begin{tabular}{|c|c|c|c|c|c|c|c|c|c|c|c|c|c|c|c|}
\hline \multirow[b]{2}{*}{$\begin{array}{c}\text { Map } \\
\text { ID } \\
\text { (fig. 1) }\end{array}$} & \multirow[b]{2}{*}{ Site name } & \multirow[b]{2}{*}{$\begin{array}{c}\text { Sample date } \\
\text { (MM/DD/ } \\
\text { YYYY) }\end{array}$} & \multirow[b]{2}{*}{$\begin{array}{c}\text { Sample } \\
\text { time }\end{array}$} & \multirow{2}{*}{$\begin{array}{l}\text { Depth of } \\
\text { sample } \\
\text { (meters } \\
\text { below land } \\
\text { surface) }\end{array}$} & \multirow{2}{*}{$\begin{array}{l}\text { Moisture } \\
\text { content, } \\
\text { soil, dry } \\
\text { weight } \\
\text { (percent) }\end{array}$} & \multirow{2}{*}{$\begin{array}{l}\text { Photo- } \\
\text { ionization } \\
\text { detector } \\
\text { reading } \\
\text { (parts per } \\
\text { million) }\end{array}$} & \multicolumn{9}{|c|}{ Concentration, in milligrams per kilogram } \\
\hline & & & & & & & Benzene & Toluene & $\begin{array}{c}\text { Ethyl- } \\
\text { benzene }\end{array}$ & $\begin{array}{c}\text { Total } \\
\text { xylenes }\end{array}$ & $\begin{array}{c}m \text { - and } \\
p \text {-xylene }\end{array}$ & $o$-xylene & $\begin{array}{l}\text { Naph- } \\
\text { thalene }\end{array}$ & $\begin{array}{c}\text { GRO } \\
\text { com- } \\
\text { pounds }\end{array}$ & $\begin{array}{c}\text { DRO } \\
\text { com- } \\
\text { pounds }\end{array}$ \\
\hline 1 & MW14-01 & $11 / 06 / 2014$ & 1000 & $5.73-5.88$ & 11 & 370 & $<0.036$ & $<0.060$ & 3.00 & 1.10 & 0.92 & 0.160 & 2.10 & 5,200 & 3,600 \\
\hline 3 & MW14-03 & $11 / 04 / 2014$ & 0930 & $5.94-6.1$ & 26 & 0.0 & $<0.052$ & $<0.087$ & $<0.087$ & $<0.26$ & $<0.17$ & $<0.087$ & $<0.43$ & 44 & E1.8 \\
\hline 4 & MW14-04 & $11 / 06 / 2014$ & 1450 & $7.41-7.53$ & 22 & 0.0 & $<0.047$ & $<0.079$ & $<0.079$ & $<0.24$ & $<0.16$ & $<0.079$ & $<0.40$ & 26 & E1.7 \\
\hline 5 & MW14-05 & $11 / 04 / 2014$ & 1110 & $4.24-4.36$ & 27 & $>15,000$ & $<0.054$ & $<0.091$ & $<0.091$ & $<0.27$ & $<0.18$ & $<0.091$ & 7.60 & 580 & 440 \\
\hline 6 & MW14-06 & $11 / 07 / 2014$ & 1040 & $7.16-7.28$ & 20 & 0.10 & $<0.047$ & $<0.078$ & $<0.078$ & $<0.23$ & $<0.16$ & $<0.078$ & $<0.39$ & 20 & E1.4 \\
\hline 7 & MW14-07 & $11 / 05 / 2014$ & 1130 & $6.43-6.64$ & 17 & 260 & $<0.043$ & $<0.071$ & 0.280 & E0.18 & 0.15 & E0.026 & E0.05 & 370 & 14.6 \\
\hline 8 & MW14-08 & $11 / 04 / 2014$ & 1230 & $2.41-2.56$ & 18 & 23.0 & $<0.044$ & $<0.074$ & $<0.074$ & $<0.22$ & $<0.15$ & $<0.074$ & E0.14 & 68 & 5.7 \\
\hline 9 & MW14-09 & $11 / 04 / 2014$ & 1600 & $5.67-5.79$ & 26 & 1,100 & $<0.055$ & $<0.092$ & $<0.092$ & $<0.28$ & $<0.18$ & $<0.092$ & E0.03 & 1,800 & 3.2 \\
\hline 12 & MW2016-01 & $12 / 20 / 2016$ & 1130 & $9.63-9.72$ & 31 & 0 & $<0.094$ & $<0.094$ & $<0.094$ & $<0.28$ & $<0.19$ & $<0.094$ & $<0.47$ & E2.7 & $<2.4$ \\
\hline 13 & MW2016-02 & $12 / 21 / 2016$ & 0830 & $7.07-7.19$ & 30 & 0 & $<0.093$ & $<0.093$ & $<0.093$ & $<0.28$ & $<0.19$ & $<0.093$ & $<0.46$ & E2.7 & $<2.3$ \\
\hline 14 & MW2016-03 & $12 / 21 / 2016$ & 1130 & $1.37-1.52$ & 18 & 18 & $<0.072$ & $<0.072$ & $<0.072$ & $<0.22$ & $<0.14$ & $<0.072$ & $<0.36$ & 28 & 330 \\
\hline
\end{tabular}


Table 8. Summary of petroleum hydrocarbon compound concentrations in groundwater samples collected from 14 monitoring wells and a recovery sump in the study area

around Fuels Area C, 2014-18.

[ID, identification; USGS, U.S. Geological Survey; GRO, gasoline-range organic; DRO, diesel-range organic; <, less than laboratory reporting level; E, compound present but concentration estimated less than the laboratory reporting level]

\begin{tabular}{|c|c|c|c|c|c|c|c|c|c|c|c|}
\hline \multirow{2}{*}{$\begin{array}{l}\text { Map ID } \\
\text { (fig. 1) }\end{array}$} & \multirow[b]{2}{*}{ Site name } & \multirow[b]{2}{*}{ Statistic } & \multicolumn{9}{|c|}{ Concentration, in micrograms per liter } \\
\hline & & & Benzene & Toluene & Ethylbenzene & $\begin{array}{c}\text { Total } \\
\text { xylenes }\end{array}$ & $\begin{array}{c}\text { m- and } \\
p \text {-Xylene }\end{array}$ & o-Xylene & Naphthalene & $\begin{array}{c}\text { GRO } \\
\text { compounds }\end{array}$ & $\begin{array}{c}\text { DRO } \\
\text { compounds }\end{array}$ \\
\hline \multirow[t]{5}{*}{1} & MW14-01 & $\begin{array}{c}\text { Number of } \\
\text { samples }\end{array}$ & 11 & 11 & 11 & 11 & 10 & 10 & 11 & 11 & 11 \\
\hline & & $\begin{array}{l}\text { Number of } \\
\text { detections }^{1}\end{array}$ & 0 & 0 & 3 & 2 & 2 & 1 & 1 & 11 & 11 \\
\hline & & Minimum & $<1.0$ & $<1.0$ & $<1.0$ & $<3.0$ & $<2.0$ & $<1.0$ & $<1.0$ & $<100$ & $<210$ \\
\hline & & Median & $<1.0$ & $<1.0$ & $<1.0$ & $<3.0$ & $<2.0$ & $<1.0$ & $<1.0$ & 240 & 310 \\
\hline & & Maximum & $<1.0$ & $<1.0$ & 6.8 & $<3.0$ & 2.3 & $<1.0$ & 4.0 & 1,200 & 1,400 \\
\hline \multirow[t]{5}{*}{2} & MW14-02 & $\begin{array}{c}\text { Number of } \\
\text { samples }\end{array}$ & 11 & 11 & 11 & 11 & 10 & 10 & 11 & 11 & 11 \\
\hline & & $\begin{array}{l}\text { Number of } \\
\text { detections }\end{array}$ & 0 & 0 & 0 & 0 & 0 & 0 & 1 & 10 & 7 \\
\hline & & Minimum & $<1.0$ & $<1.0$ & $<1.0$ & $<3.0$ & $<2.0$ & $<1.0$ & $<1.0$ & $<100$ & $<210$ \\
\hline & & Median & $<1.0$ & $<1.0$ & $<1.0$ & $<3.0$ & $<2.0$ & $<1.0$ & $<1.0$ & $<100$ & $<210$ \\
\hline & & Maximum & $<1.0$ & $<1.0$ & $<1.0$ & $<3.0$ & $<2.0$ & $<1.0$ & $<1.0$ & 120 & $<210$ \\
\hline \multirow[t]{5}{*}{3} & MW14-03 & $\begin{array}{c}\text { Number of } \\
\text { samples }\end{array}$ & 10 & 10 & 10 & 10 & 9 & 9 & 10 & 10 & 10 \\
\hline & & $\begin{array}{l}\text { Number of } \\
\text { detections }\end{array}$ & 0 & 0 & 0 & 0 & 0 & 0 & 0 & 9 & 9 \\
\hline & & Minimum & $<1.0$ & $<1.0$ & $<1.0$ & $<3.0$ & $<2.0$ & $<1.0$ & $<1.0$ & $<100$ & $<210$ \\
\hline & & Median & $<1.0$ & $<1.0$ & $<1.0$ & $<3.0$ & $<2.0$ & $<1.0$ & $<1.0$ & $<100$ & 390 \\
\hline & & Maximum & $<1.0$ & $<1.0$ & $<1.0$ & $<3.0$ & $<2.0$ & $<1.0$ & $<1.0$ & $<100$ & 790 \\
\hline \multirow[t]{5}{*}{4} & MW14-04 & $\begin{array}{c}\text { Number of } \\
\text { samples }\end{array}$ & 11 & 11 & 11 & 11 & 10 & 10 & 11 & 11 & 11 \\
\hline & & $\begin{array}{l}\text { Number of } \\
\text { detections }\end{array}$ & 0 & 1 & 0 & 0 & 0 & 0 & 0 & 11 & 10 \\
\hline & & Minimum & $<1.0$ & $<1.0$ & $<1.0$ & $<3.0$ & $<2.0$ & $<1.0$ & $<1.0$ & $<100$ & $<210$ \\
\hline & & Median & $<1.0$ & $<1.0$ & $<1.0$ & $<3.0$ & $<2.0$ & $<1.0$ & $<1.0$ & $<100$ & $<210$ \\
\hline & & Maximum & $<1.0$ & $<1.0$ & $<1.0$ & $<3.0$ & $<2.0$ & $<1.0$ & $<1.0$ & 260 & 630 \\
\hline
\end{tabular}


Table 8. Summary of petroleum hydrocarbon compound concentrations in groundwater samples collected from 14 monitoring wells and a recovery sump in the study area around Fuels Area C, 2014-18.-Continued

[ID, identification; USGS, U.S. Geological Survey; GRO, gasoline-range organic; DRO, diesel-range organic; <, less than laboratory reporting level; E, compound present but concentration estimated less than the laboratory reporting level]

\begin{tabular}{|c|c|c|c|c|c|c|c|c|c|c|c|}
\hline \multirow{2}{*}{$\begin{array}{l}\text { Map ID } \\
\text { (fig. 1) }\end{array}$} & \multirow[b]{2}{*}{ Site name } & \multirow[b]{2}{*}{ Statistic } & \multicolumn{9}{|c|}{ Concentration, in micrograms per liter } \\
\hline & & & Benzene & Toluene & Ethylbenzene & $\begin{array}{c}\text { Total } \\
\text { xylenes }\end{array}$ & $\begin{array}{c}m \text { - and } \\
p \text {-Xylene }\end{array}$ & o-Xylene & Naphthalene & $\begin{array}{c}\text { GRO } \\
\text { compounds }\end{array}$ & $\begin{array}{c}\text { DRO } \\
\text { compounds }\end{array}$ \\
\hline \multirow[t]{5}{*}{5} & MW14-05 & $\begin{array}{c}\text { Number of } \\
\text { samples }\end{array}$ & 9 & 9 & 9 & 9 & 8 & 8 & 9 & 9 & 9 \\
\hline & & $\begin{array}{l}\text { Number of } \\
\text { detections }\end{array}$ & 8 & 0 & 0 & 0 & 0 & 0 & 3 & 9 & 9 \\
\hline & & Minimum & $<1.0$ & $<1.0$ & $<1.0$ & $<3.0$ & $<2.0$ & $<1.0$ & $<1.0$ & $<100$ & $<210$ \\
\hline & & Median & $<1.0$ & $<1.0$ & $<1.0$ & $<3.0$ & $<2.0$ & $<1.0$ & $<1.0$ & 150 & 610 \\
\hline & & Maximum & 1.1 & $<1.0$ & $<1.0$ & $<3.0$ & $<2.0$ & $<1.0$ & 29 & 400 & 1,300 \\
\hline \multirow[t]{5}{*}{6} & MW14-06 & $\begin{array}{c}\text { Number of } \\
\text { samples }\end{array}$ & 11 & 11 & 11 & 11 & 9 & 9 & 11 & 11 & 11 \\
\hline & & $\begin{array}{l}\text { Number of } \\
\text { detections }\end{array}$ & 0 & 0 & 0 & 0 & 0 & 0 & 0 & 10 & 10 \\
\hline & & Minimum & $<1.0$ & $<1.0$ & $<1.0$ & $<3.0$ & $<2.0$ & $<1.0$ & $<1.0$ & $<100$ & $<210$ \\
\hline & & Median & $<1.0$ & $<1.0$ & $<1.0$ & $<3.0$ & $<2.0$ & $<1.0$ & $<1.0$ & $<100$ & $<210$ \\
\hline & & Maximum & $<1.0$ & $<1.0$ & $<1.0$ & $<3.0$ & $<2.0$ & $<1.0$ & $<1.0$ & $<100$ & 430 \\
\hline \multirow[t]{5}{*}{7} & MW14-07 & $\begin{array}{c}\text { Number of } \\
\text { samples }\end{array}$ & 11 & 11 & 11 & 11 & 10 & 10 & 11 & 11 & 11 \\
\hline & & $\begin{array}{l}\text { Number of } \\
\text { detections }\end{array}$ & 0 & 0 & 1 & 1 & 1 & 1 & 1 & 9 & 8 \\
\hline & & Minimum & $<1.0$ & $<1.0$ & $<1.0$ & $<3.0$ & $<2.0$ & $<1.0$ & $<1.0$ & $<100$ & $<210$ \\
\hline & & Median & $<1.0$ & $<1.0$ & $<1.0$ & $<3.0$ & $<2.0$ & $<1.0$ & $<1.0$ & $<100$ & $<210$ \\
\hline & & Maximum & $<1.0$ & $<1.0$ & 64 & 30 & 27 & E2.0 & 33 & 2,600 & 2,400 \\
\hline \multirow[t]{5}{*}{8} & MW14-08 & $\begin{array}{c}\text { Number of } \\
\text { samples }\end{array}$ & 1 & 1 & 1 & 1 & 0 & 0 & 1 & 1 & 1 \\
\hline & & $\begin{array}{l}\text { Number of } \\
\text { detections }\end{array}$ & 0 & 0 & 0 & 0 & 0 & 0 & 0 & 1 & 1 \\
\hline & & Minimum & $<1.0$ & $<1.0$ & $<1.0$ & $<3.0$ & $<2.0$ & $<1.0$ & $<1.0$ & $<100$ & 1,100 \\
\hline & & Median & $<1.0$ & $<1.0$ & $<1.0$ & $<3.0$ & $<2.0$ & $<1.0$ & $<1.0$ & $<100$ & 1,100 \\
\hline & & Maximum & $<1.0$ & $<1.0$ & $<1.0$ & $<3.0$ & $<2.0$ & $<1.0$ & $<1.0$ & $<100$ & 1,100 \\
\hline
\end{tabular}


Table 8. Summary of petroleum hydrocarbon compound concentrations in groundwater samples collected from 14 monitoring wells and a recovery sump in the study area around Fuels Area C, 2014-18.-Continued

[ID, identification; USGS, U.S. Geological Survey; GRO, gasoline-range organic; DRO, diesel-range organic; <, less than laboratory reporting level; E, compound present but concentration estimated less than the laboratory reporting level]

\begin{tabular}{|c|c|c|c|c|c|c|c|c|c|c|c|}
\hline \multirow{2}{*}{$\begin{array}{l}\text { Map ID } \\
\text { (fig. 1) }\end{array}$} & \multirow[b]{2}{*}{ Site name } & \multirow[b]{2}{*}{ Statistic } & \multicolumn{9}{|c|}{ Concentration, in micrograms per liter } \\
\hline & & & Benzene & Toluene & Ethylbenzene & $\begin{array}{c}\text { Total } \\
\text { xylenes }\end{array}$ & $\begin{array}{c}m \text { - and } \\
p \text {-Xylene }\end{array}$ & o-Xylene & Naphthalene & $\begin{array}{c}\text { GRO } \\
\text { compounds }\end{array}$ & $\begin{array}{c}\text { DRO } \\
\text { compounds }\end{array}$ \\
\hline \multirow[t]{5}{*}{9} & MW14-09 & $\begin{array}{c}\text { Number of } \\
\text { samples }\end{array}$ & 11 & 11 & 11 & 11 & 9 & 9 & 11 & 11 & 11 \\
\hline & & $\begin{array}{l}\text { Number of } \\
\text { detections }\end{array}$ & 0 & 0 & 0 & 0 & 0 & 0 & 2 & 10 & 11 \\
\hline & & Minimum & $<1.0$ & $<1.0$ & $<1.0$ & $<3.0$ & $<2.0$ & $<1.0$ & $<1.0$ & $<100$ & $<210$ \\
\hline & & Median & $<1.0$ & $<1.0$ & $<1.0$ & $<3.0$ & $<2.0$ & $<1.0$ & $<1.0$ & 110 & 480 \\
\hline & & Maximum & $<1.0$ & $<1.0$ & $<1.0$ & $<3.0$ & $<2.0$ & $<1.0$ & $<1.0$ & 750 & 1,700 \\
\hline \multirow[t]{5}{*}{10} & MW08C01 & $\begin{array}{c}\text { Number of } \\
\text { samples }\end{array}$ & 10 & 10 & 10 & 10 & 9 & 9 & 10 & 10 & 10 \\
\hline & & $\begin{array}{l}\text { Number of } \\
\text { detections }^{1}\end{array}$ & 10 & 0 & 10 & 9 & 8 & 8 & 4 & 10 & 10 \\
\hline & & Minimum & 119 & $<1.0$ & 10 & $<3.0$ & $<2.0$ & $<1.0$ & $<1.0$ & 1,500 & 9,600 \\
\hline & & Median & 155 & $<1.0$ & 17 & 7.7 & 5.6 & 2.1 & $<1.0$ & 2,450 & 28,000 \\
\hline & & Maximum $^{1}$ & 190 & $<1.0$ & 43 & 57 & 55 & 7.0 & 24.5 & 9,700 & 55,000 \\
\hline \multirow[t]{5}{*}{11} & MW11C02 & $\begin{array}{c}\text { Number of } \\
\text { samples }\end{array}$ & 10 & 10 & 10 & 10 & 9 & 9 & 10 & 10 & 10 \\
\hline & & $\begin{array}{l}\text { Number of } \\
\text { detections }^{1}\end{array}$ & 9 & 4 & 9 & 8 & 9 & 6 & 9 & 10 & 10 \\
\hline & & Minimum $^{1}$ & $<1.0$ & $<1.0$ & $<1.0$ & $<3.0$ & E5.2 & 2.3 & $<1.0$ & $<100$ & 560 \\
\hline & & Median & 1,280 & $<1.0$ & 69 & 330 & 320 & 14 & 44 & 4,300 & 1,950 \\
\hline & & Maximum & 2,900 & 6.6 & 160 & 880 & 870 & 21 & 94 & 13,000 & 7,300 \\
\hline \multirow[t]{5}{*}{12} & MW2016-01 & $\begin{array}{c}\text { Number of } \\
\text { samples }\end{array}$ & 6 & 6 & 6 & 6 & 5 & 5 & 6 & 6 & 6 \\
\hline & & $\begin{array}{l}\text { Number of } \\
\text { detections }\end{array}$ & 0 & 1 & 1 & 0 & 0 & 0 & 0 & 5 & 6 \\
\hline & & Minimum & $<1.0$ & $<1.0$ & $<1.0$ & $<3.0$ & $<2.0$ & $<1.0$ & $<1.0$ & $<100$ & $<210$ \\
\hline & & Median & $<1.0$ & $<1.0$ & $<1.0$ & $<3.0$ & $<2.0$ & $<1.0$ & $<1.0$ & $<100$ & 220 \\
\hline & & Maximum & $<1.0$ & $<1.0$ & $<1.0$ & $<3.0$ & $<2.0$ & $<1.0$ & $<1.0$ & 210 & 1,100 \\
\hline
\end{tabular}


Table 8. Summary of petroleum hydrocarbon compound concentrations in groundwater samples collected from 14 monitoring wells and a recovery sump in the study area around Fuels Area C, 2014-18.-Continued

[ID, identification; USGS, U.S. Geological Survey; GRO, gasoline-range organic; DRO, diesel-range organic; <, less than laboratory reporting level; E, compound present but concentration estimated less than the laboratory reporting level]

\begin{tabular}{|c|c|c|c|c|c|c|c|c|c|c|c|}
\hline \multirow{2}{*}{$\begin{array}{l}\text { Map ID } \\
\text { (fig. 1) }\end{array}$} & \multirow[b]{2}{*}{ Site name } & \multirow[b]{2}{*}{ Statistic } & \multicolumn{9}{|c|}{ Concentration, in micrograms per liter } \\
\hline & & & Benzene & Toluene & Ethylbenzene & $\begin{array}{c}\text { Total } \\
\text { xylenes }\end{array}$ & $\begin{array}{c}m \text { - and } \\
p \text {-Xylene }\end{array}$ & o-Xylene & Naphthalene & $\begin{array}{c}\text { GRO } \\
\text { compounds }\end{array}$ & $\begin{array}{c}\text { DRO } \\
\text { compounds }\end{array}$ \\
\hline \multirow[t]{5}{*}{13} & MW2016-02 & $\begin{array}{c}\text { Number of } \\
\text { samples }\end{array}$ & 6 & 6 & 6 & 6 & 5 & 5 & 6 & 6 & 6 \\
\hline & & $\begin{array}{l}\text { Number of } \\
\text { detections }\end{array}$ & 1 & 0 & 0 & 0 & 1 & 0 & 0 & 4 & 6 \\
\hline & & Minimum & $<1.0$ & $<1.0$ & $<1.0$ & $<3.0$ & $<2.0$ & $<1.0$ & $<1.0$ & $<100$ & $<210$ \\
\hline & & Median & $<1.0$ & $<1.0$ & $<1.0$ & $<3.0$ & $<2.0$ & $<1.0$ & $<1.0$ & $<100$ & 350 \\
\hline & & Maximum & $<1.0$ & $<1.0$ & $<1.0$ & $<3.0$ & $<2.0$ & $<1.0$ & $<1.0$ & 140 & 6,100 \\
\hline \multirow[t]{5}{*}{14} & MW2016-03 & $\begin{array}{c}\text { Number of } \\
\text { samples }\end{array}$ & 6 & 6 & 6 & 6 & 5 & 5 & 6 & 6 & 6 \\
\hline & & $\begin{array}{l}\text { Number of } \\
\text { detections }\end{array}$ & 1 & 0 & 0 & 0 & 0 & 0 & 0 & 5 & 5 \\
\hline & & Minimum & $<1.0$ & $<1.0$ & $<1.0$ & $<3.0$ & $<2.0$ & $<1.0$ & $<1.0$ & $<100$ & $<210$ \\
\hline & & Median & $<1.0$ & $<1.0$ & $<1.0$ & $<3.0$ & $<2.0$ & $<1.0$ & $<1.0$ & $<100$ & 230 \\
\hline & & Maximum & 2.4 & $<1.0$ & $<1.0$ & $<3.0$ & $<2.0$ & $<1.0$ & $<1.0$ & 120 & 430 \\
\hline \multirow[t]{5}{*}{15} & $\begin{array}{l}\text { Recovery } \\
\text { Sump }\end{array}$ & $\begin{array}{c}\text { Number of } \\
\text { samples }\end{array}$ & 5 & 5 & 5 & 5 & 4 & 4 & 5 & 5 & 5 \\
\hline & & $\begin{array}{l}\text { Number of } \\
\text { detections }\end{array}$ & 1 & 0 & 0 & 0 & 0 & 0 & 1 & 3 & 5 \\
\hline & & Minimum & $<1.0$ & $<1.0$ & $<1.0$ & $<3.0$ & $<2.0$ & $<1.0$ & $<1.0$ & $<100$ & 220 \\
\hline & & Median & $<1.0$ & $<1.0$ & $<1.0$ & $<3.0$ & $<2.0$ & $<1.0$ & $<1.0$ & $<100$ & 540 \\
\hline & & Maximum & 1.2 & $<1.0$ & $<1.0$ & $<3.0$ & $<2.0$ & $<1.0$ & 1.3 & 380 & 7,700 \\
\hline
\end{tabular}

${ }^{1}$ Much higher laboratory reporting levels were used for several samples and were not included in the statistics in this table. 


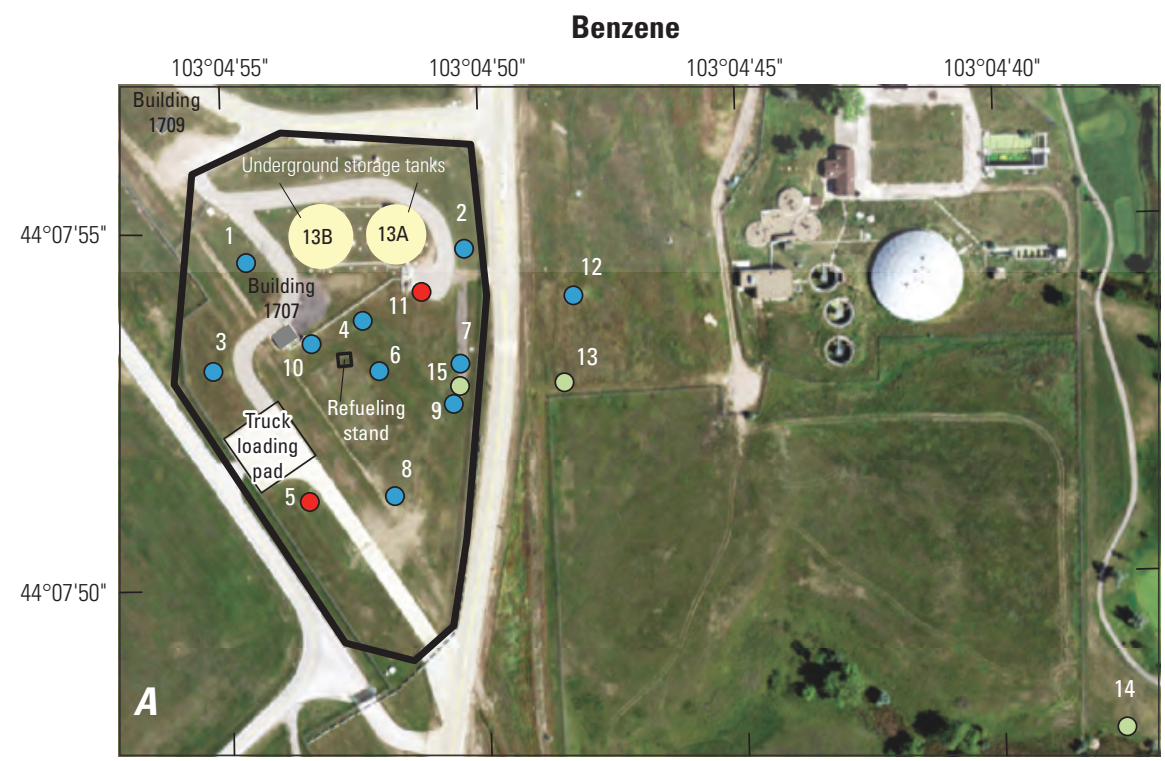

Ethylbenzene

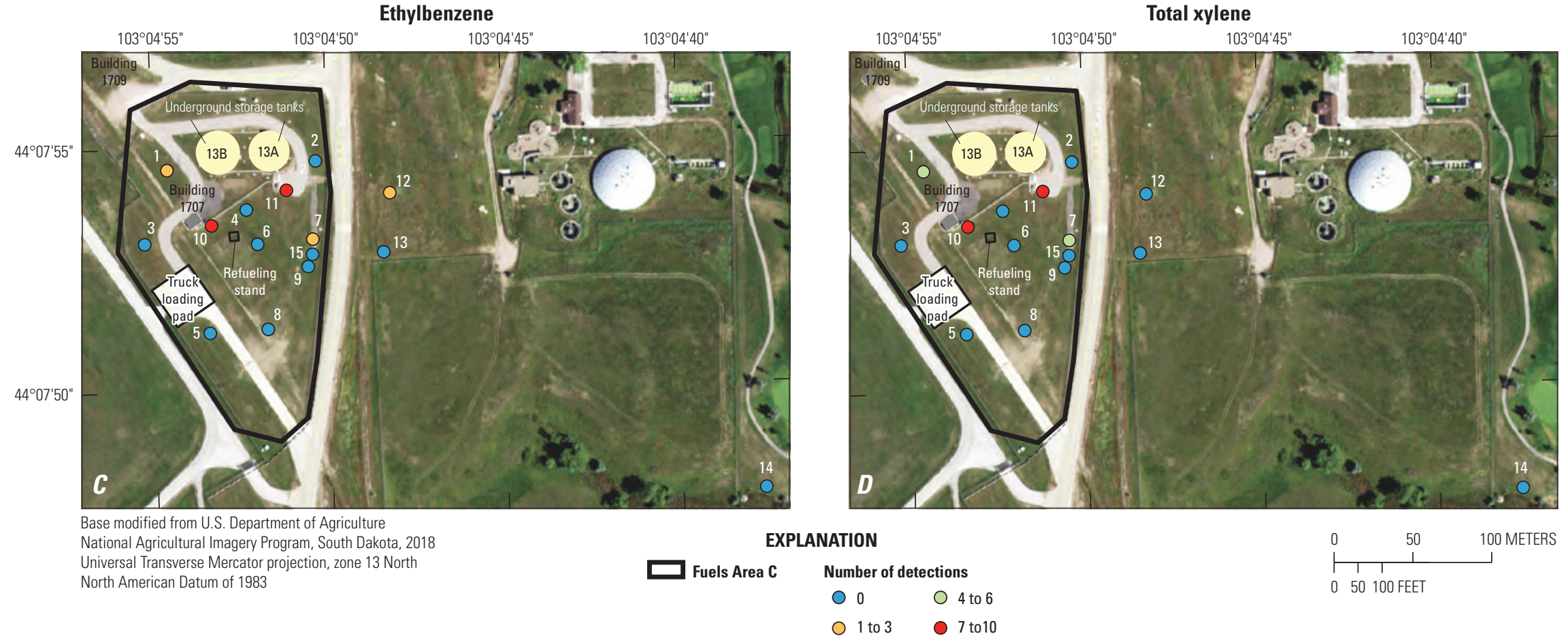

Figure 4. Number and location of detections for BTEX compounds in samples collected at sites in the study area around Fuels Area $C, 2014-18$. $A, B e n z e n e . ~ B$, Toluene. $C$, Ethylbenzene. D, Total xylene.

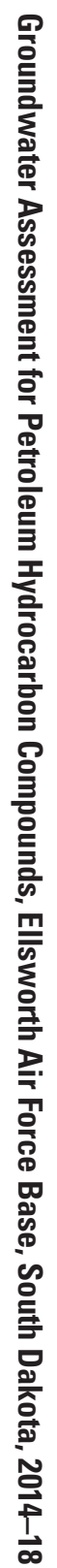

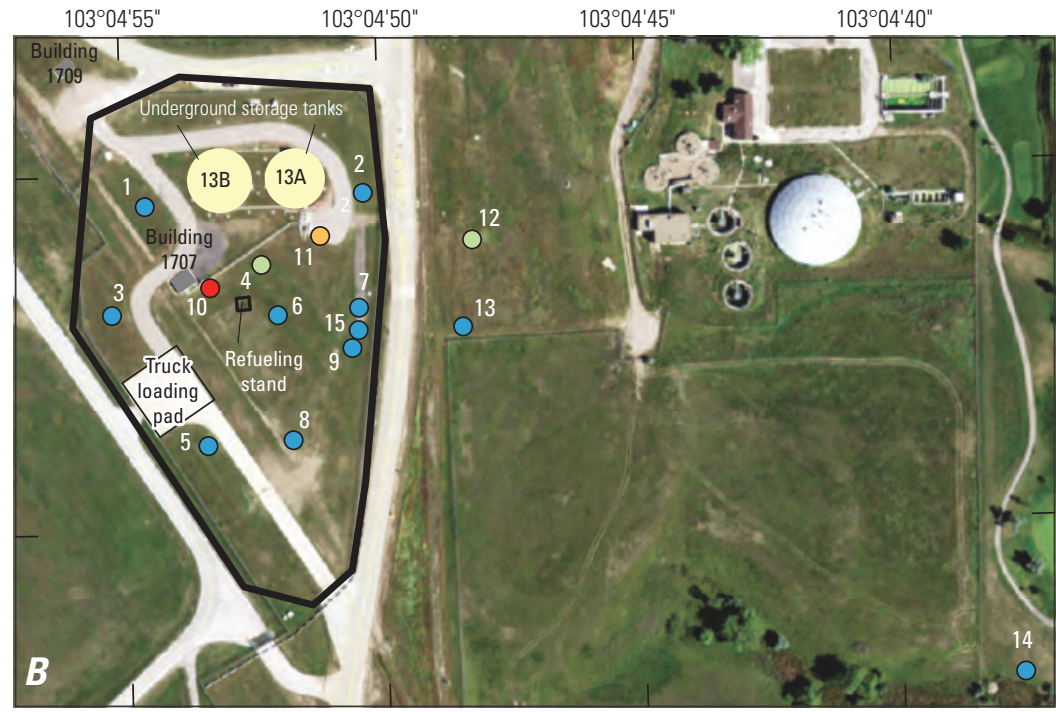

Total xylene

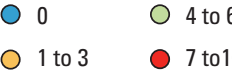


sites outside of and downgradient from Fuels Area C (sites 12-14, fig. 4). Benzene was only detected in samples collected in June 2017 at sites 13 and 14. Toluene and ethylbenzene were detected in one sample from site 12 , but not in any samples from sites 13 and 14 (figs. $4 B$ and $4 C$ ). Total xylenes were only detected at sites within Fuels Area C (sites 7, 10, and 11; fig. $4 D$ ), but $m$ - and $p$-xylene was detected in one sample collected in April 2017 from site 13 outside of Fuels Area C (table 8).

Measurable BTEX compound concentrations in most of the wells sampled in 2014-18 in the study area were either below the LRL or slightly greater than the LRL, except for samples collected at sites 7,10, and 11. At site 7, one sample collected in November 2014 had concentrations of ethylbenzene, total xylenes, $m$ - and $p$-xylene, and $o$-xylene of 64,30 , 27 , and 2.0 (estimated) $\mu \mathrm{g} / \mathrm{L}$, respectively (table 8 ). All other samples from site 7 did not have detectable concentrations of BTEX compounds. Concentrations measured at site 10 varied with individual BTEX compounds. Benzene concentrations were detected in all 10 samples and ranged from 119 to $190 \mu \mathrm{g} / \mathrm{L}$ at site 10 . All concentrations were greater than the EPA MCL of $5 \mu \mathrm{g} / \mathrm{L}$ (tables 3 and 8). Toluene was not detected at concentrations above the LRL in any of the samples. Ethylbenzene had measurable concentrations above the LRL in all 10 samples from site 10 , ranging from 10 to $43 \mu \mathrm{g} / \mathrm{L}$, all below the EPA MCL of $700 \mu \mathrm{g} / \mathrm{L}$ (tables 3 and 8). Xylene compounds (total xylene, $m$ - and $p$-xylene, and $o$-xylene) were detected in 9 out of 10 samples collected at site 10. Most concentrations were less than $10 \mu \mathrm{g} / \mathrm{L}$ except for samples collected in June 2015 and April 2017, which had total xylene concentrations of 57 and $25 \mu \mathrm{g} / \mathrm{L}$, respectively, and $m$ - and $p$-xylene concentrations of 55 and $17 \mu \mathrm{g} / \mathrm{L}$, respectively (table 2.1).

BTEX compound concentrations generally were the highest and most variable at site 11 compared to the other sites sampled in the study area from 2014 to 2018 (table 8). Benzene concentrations were detected in 10 of 11 samples and measurable concentrations ranged from 15 to $2,900 \mu \mathrm{g} / \mathrm{L}$. All measurable concentrations were greater than the EPA MCL of $5 \mu \mathrm{g} / \mathrm{L}$ (tables 8 and 3). Toluene was detected above the LRL in one sample collected in June 2016 with a concentration of $6.6 \mu \mathrm{g} / \mathrm{L}$ (table 2.1). Toluene also was detected in three other samples from site 11, but the concentrations were all below the LRL. Two samples collected in December 2017 and April 2018 had toluene concentrations below the LRL, but the LRL was set to a higher value $(50 \mu \mathrm{g} / \mathrm{L})$ by the laboratory for those samples (table 2.1). If there are interferences in the sample matrix, a laboratory often uses a higher LRL because of higher uncertainty in the quantification of concentration. Ethylbenzene had measurable concentrations above the LRL in 8 of 10 samples from site 11 with measurable concentrations ranging from 16 to $160 \mu \mathrm{g} / \mathrm{L}$, which were all below the EPA MCL of $700 \mu \mathrm{g} / \mathrm{L}$ (tables 3 and 8). Ethylbenzene was detected in one other sample, but the concentration was below the LRL that was set to a higher value of $5.0 \mu \mathrm{g} / \mathrm{L}$ by the laboratory. Total xylenes were detected in 8 of 10 samples at site 11 with measurable concentrations ranging from 50 to $880 \mu \mathrm{g} / \mathrm{L}$, which were well below the EPA MCL of 10,000 $\mu \mathrm{g} / \mathrm{L}$. Concentrations of $m$ - and $p$-xylene ranged from 5.2 (estimated) to $870 \mu \mathrm{g} / \mathrm{L}$ and $o$-xylene had concentrations ranging from 2.3 to $21 \mu \mathrm{g} / \mathrm{L}$ (table 8 ). Site 11 had two samples collected in December 2017 and April 2018 with $o$-xylene concentrations considered not detected, but the LRL was set to a higher value $(50 \mu \mathrm{g} / \mathrm{L})$ by the laboratory for those samples possibly because of matrix interference affecting the laboratory analysis in those samples (table 2.1).

Naphthalene was detected in 8 of the 15 sites sampled in the study area in 2014-18 (fig. 5, table 8). The number of naphthalene detections was highest on the east side of Fuel Area $\mathrm{C}$ with the most detections at site 11 southeast of UST 13A (fig. 5). Detections of measurable naphthalene concentrations were in 2014 and 2015 at site 1 (1 out of 3 samples), site 2 ( 1 out of 3 samples), site 5 (both samples), site 7 (1 out of 3 samples), and site 9 (2 out of 3 samples); detected concentrations for site 9 were all below the LRL. Naphthalene was detected in 9 of 10 samples collected from site 11 and 4 out of 10 samples collected at site 10. One sample collected in September 2017 from the recovery sump (site 15) had a detectable concentration slightly greater than the LRL, but naphthalene was not detected in other samples collected from the site (table 2.1). Naphthalene was not detected in any samples from the sites outside and east of Fuels Area C (sites 12-14; fig. 5).

Measurable concentrations of naphthalene generally were less than $5 \mu \mathrm{g} / \mathrm{L}$ in wells sampled in the study area in 2014-18 except for samples collected at sites 5, 7, and 11 (table 8). Samples from site 5 collected in June and October 2015 had concentrations of 21 and $29 \mu \mathrm{g} / \mathrm{L}$, respectively, with subsequent samples less than the LRL (table 2.1). Site 7 had one sample with a detectable concentration of $33 \mu \mathrm{g} / \mathrm{L}$ collected in November 2014. Site 11 had the highest and most variable concentrations of naphthalene among the sites ranging from less than 1.0 to $94 \mu \mathrm{g} / \mathrm{L}$ (table 8 ). Only 1 out of the 10 total samples collected at site 11 had a concentration below the LRL; however, the EPA does not have an established MCL for naphthalene for comparison.

The variability of the presence of BTEX compounds and naphthalene in wells sampled in the study area during 2014-18 likely is caused by the variability in the subsurface material, local groundwater flow, operational fueling activities, and historical spills and releases in the area. Information from soil borings and the electrical resistivity surveys indicate variable subsurface material ranging from more transmissive and coarser material (sand and gravels) to finer and less transmissive materials (silts and clays). Although the potentiometric surface indicates an eastward groundwater-flow direction in the study area, variations in subsurface geologic materials could create highly variable flow paths on a smaller scale in the study area. The potentiometric surface map also shows a very low gradient in the potentiometric surface at Fuels Area $\mathrm{C}$, indicating that groundwater movement is somewhat slow. The spatial and temporal variability in the BTEX compounds 


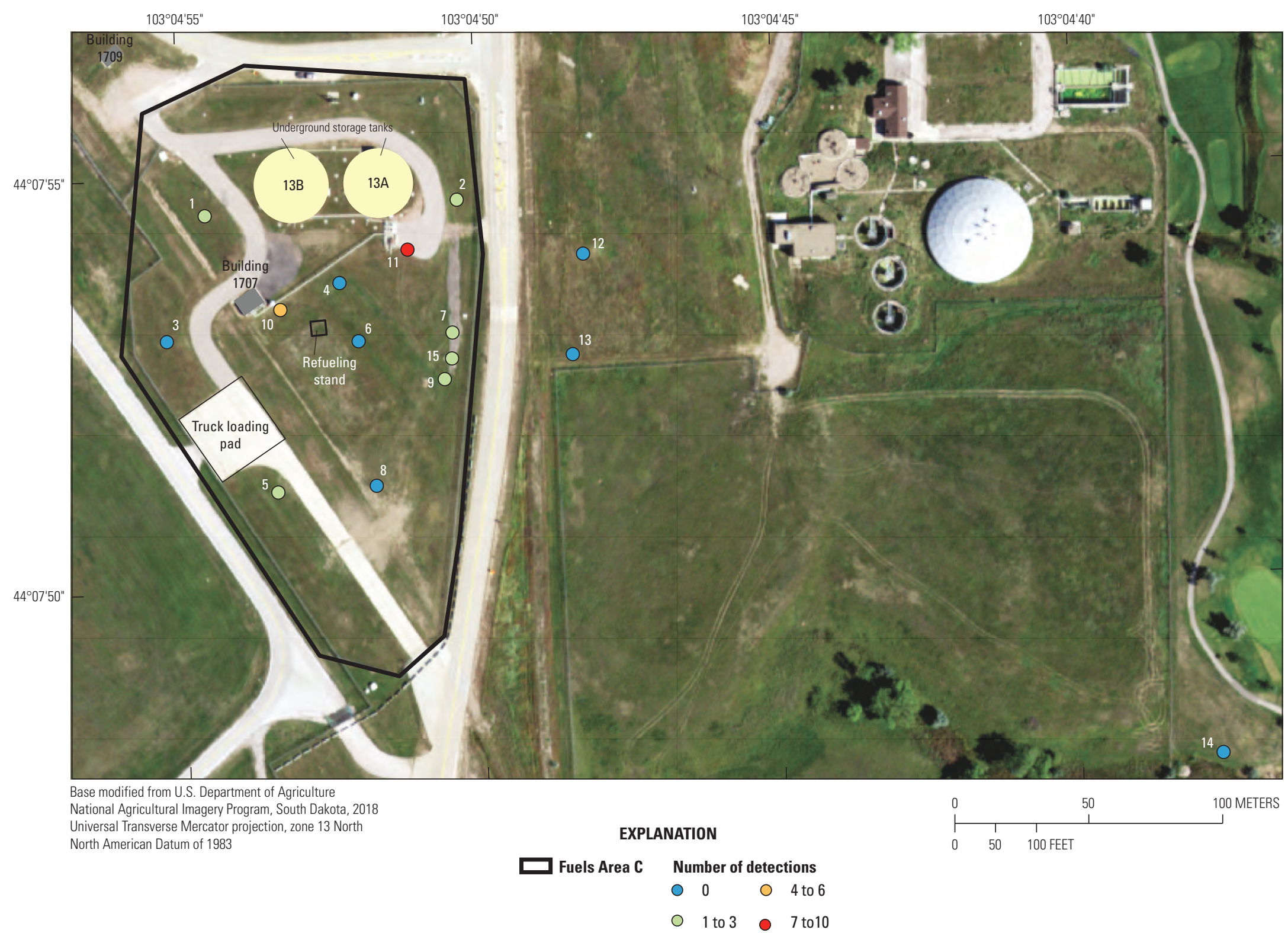

Figure 5. Number and location of detections of naphthalene in samples collected in the study area around Fuels Area C, 2014-18. 
and naphthalene concentration from samples collected from 2014 to 2018 do not indicate a consistent pattern of subsurface flow or contaminant movement that would be expected if a contaminant plume migrated with the flow and movement of groundwater. Many wells had detectable concentrations of petroleum products only in a few samples and mostly in samples collected in 2014 and 2015. This observation indicates that contaminant migration could be affected by other hydrogeological characteristics of the area other than groundwater-flow paths, such as possible migration of petroleum compounds from surface activities to the subsurface following rainfall events.

Several spills were documented in the study area (table 1) and the largest volume spill was in June 2015. In June 2015, a spill event was recorded of 3,400 liters (900 gallons) of Jet A fuel leaked to the subsurface from UST 13B (fig. 1, table 1). Samples collected in the study area from 2014 to 2018 contained reportable concentrations of BTEX compounds and naphthalene in only a few samples, which did not indicate persistent or widespread contamination from the spill in the subsurface. Samples from well sites 10 and 11 contained high concentrations of BTEX in many of the samples collected from 2014 to 2018. However, samples collected for studies before 2015 also contained elevated concentrations of BTEX at sites 10 and 11 (Tetra Tech Incorporated, 2008). The high concentrations of BTEX before and after the June 2015 spill indicate that the petroleum hydrocarbons are probably from other sources, previous releases, or other spills. Site 10 is upgradient from UST 13B (fig. 1) and spills and seepage from the USTs likely would not reach this well. Petroleum products from a spill in March 1993 at Building 1707, west and upgradient from site 10 (fig. 1; table 1), could be the source of petroleum product detected at site 10. Additionally, spills were documented at the refueling stand in November 1992 and the truck loading pad in September 1994 (fig. 1; table 1). The groundwater-flow direction (fig. 3) is east of the refueling stand and the truck loading pad and may indicate those previous spills have affected hydrocarbon concentrations at sites 10 and 11, which are downgradient from those sites.

\section{Gasoline-Range and Diesel-Range Organics}

GROs and DROs were detected in most of the samples collected in the study area around Fuels Area C in 2014-18; however, concentrations often were less than the LRL (table 8). Median GRO concentrations were greater than the LRL at sites 1, 5, 9, 10, and 11 (fig. 6). Median DRO concentrations were greater than the LRL at most sites except sites 2, 4, 6, and 7. The highest concentrations of GROs and DROs generally were observed in samples collected from sites 10 and 11 (table 8; fig. 6). GRO concentrations ranged from 1,500 to $9,700 \mu \mathrm{g} / \mathrm{L}$ at site 10 and from less than 100 to $13,000 \mu \mathrm{g} / \mathrm{L}$ at site 11 . DRO concentrations ranged from 9,600 to $55,000 \mu \mathrm{g} / \mathrm{L}$ at site 10 and from 560 to $7,300 \mu \mathrm{g} / \mathrm{L}$ at site 11 .

Many of the sites had detectable concentrations of GROs and DROs but had no detectable concentrations of BTEX compounds, except sites 10 and 11 (table 8, figs. 4-6). Studies at other fuel release sites have determined that GRO compound concentrations can remain stable during long periods of time, and DRO analyses can contain polar compounds that can be nonfuel related in groundwater and are typically oxygencontaining metabolites of hydrocarbon biodegradation at fuel release sites (Zemo and others, 2017). In other words, remnants of past spills in the form of nonfuel polar compounds may still be detected in the analysis of DROs, although BTEX compounds are no longer detected at the sites. The presence of GRO and DRO concentrations and absence of BTEX in samples in the study area indicate that previous fuel spills and releases in the area may still be affecting the groundwater chemistry in the area, but do not seem to indicate widespread petroleum hydrocarbon plume migration at the sampling sites. Given the variability in the detections and concentrations of petroleum hydrocarbons at sites in the study area, continued monitoring over the range of hydrologic conditions would prove helpful in better understanding the processes that affect the presence, concentration, and movement of hydrocarbons in the area. 


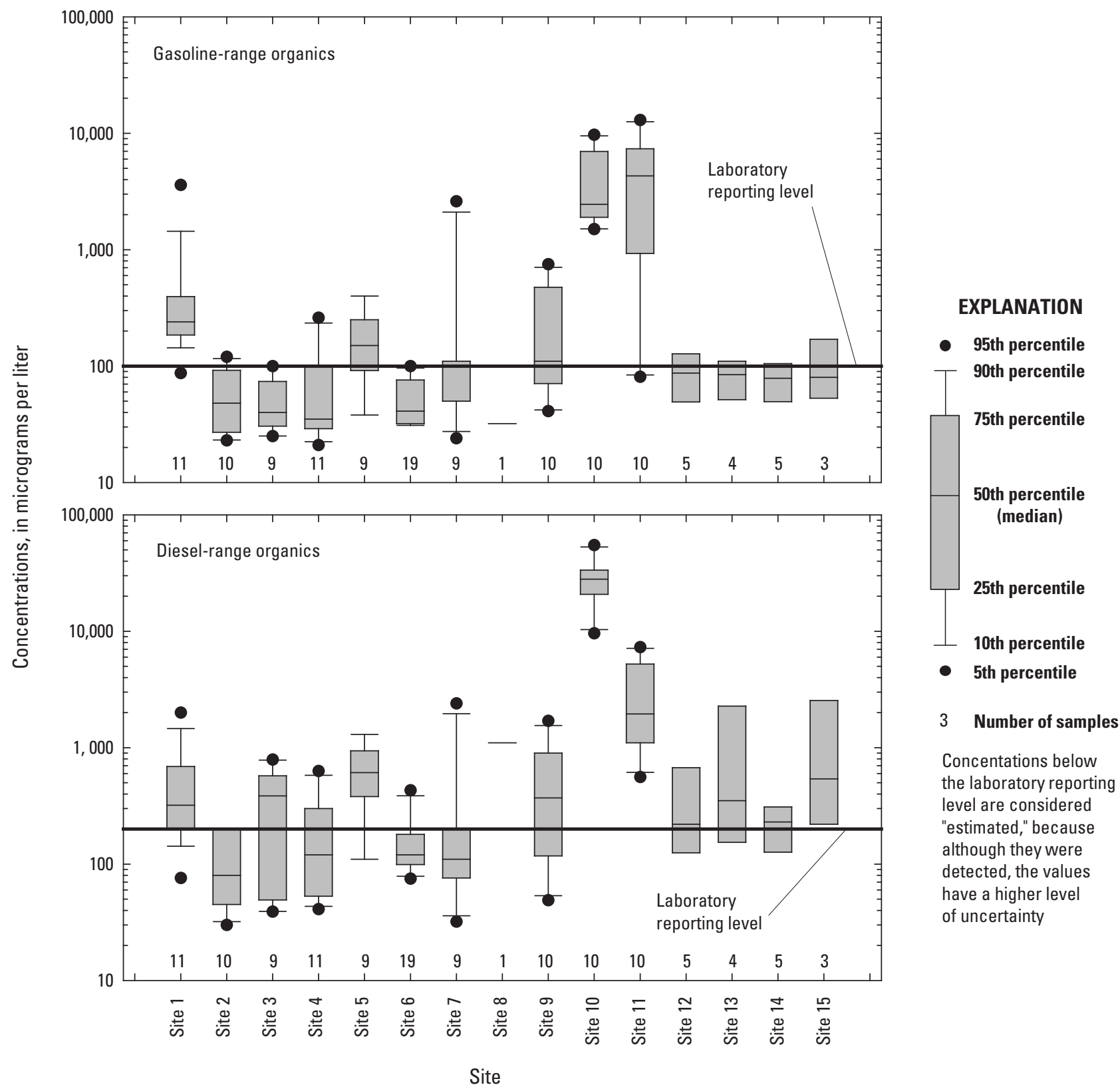

Figure 6. Distribution of gasoline-range and diesel-range organic compound concentrations in 14 monitoring wells and a recovery sump sampled in the study area around Fuels Area C, 2014-18.

\section{Summary}

In 2013, the U.S. Geological Survey began a study in cooperation with the Defense Logistics Agency and the U.S. Air Force to estimate groundwater-flow direction, install groundwater monitoring wells, and collect soil and groundwater samples for petroleum hydrocarbon compounds to identify the presence of the hydrocarbon contamination at Ellsworth Air Force Base, South Dakota, specifically around Fuels Area C. Several fuel spills of diesel fuel, jet fuel, and other petroleum products, were documented on or near Fuels Area C and several studies have been done to determine the extent of petroleum hydrocarbon contamination in the subsurface.

Two-dimensional electrical resistivity tomography surveys were conducted at Fuels Area C in 2014 to characterize subsurface materials and determine the depth to bedrock along survey lines. Determining the depth to the top of the Pierre Shale was important because variations in the bedrock surface may affect groundwater-flow paths. The depth to the top of the Pierre Shale from land surface along the four electrical resistivity tomography survey lines in Fuels area $\mathrm{C}$ ranged from 
about 5.4 to 8.7 meters. Resistivity lines and lithologic logs in wells in the area indicated mostly clay material with minor occurrences of sand and gravel.

Discrete groundwater levels were collected concurrently with water-quality sampling between November 2014 and June 2018 at 14 monitoring wells for use in generating a potentiometric surface in the study area around Fuels Area C. Potentiometric contours were used to determine groundwaterflow direction, which was assumed to be perpendicular to the contours. The potentiometric contours indicated that groundwater flow was from the west to east or southwest to southeast around Fuels Area C.

Soil and groundwater samples were collected at selected locations from 2014 to 2018 to better understand the presence and movement of petroleum hydrocarbons in the study area around Fuels Area C. Soil samples were collected at eight wells during installation in 2014 and three wells during installation in 2016. Groundwater samples were collected from 14 wells and a recovery sump within or near Fuels Area C from 2014 to 2018.

Several petroleum hydrocarbon compounds were detected, but below action levels, in soil samples collected in 2014 and 2016. Benzene and toluene were not detected in any of the soil samples from the 11 monitoring well sites. Ethylbenzene was detected at sites 1 and 7 with concentrations of 3.00 and 0.28 milligram per kilogram, respectively. Total xylenes at site 1 and 7 had concentrations of 1.1 and 0.18 (estimated) milligram per kilogram, respectively, and both were two orders of magnitude below the Tier 1 action level of 300 milligrams per kilogram. Naphthalene was detected in samples from five sites (sites 1, 5, 7, 8, and, 9), but concentrations were less than the Tier 1 action level of 25 milligrams per kilogram.

Gasoline-range organic compounds were detected in all soil samples collected during the installation of 11 groundwater monitoring wells within or near Fuels Area C in 2014 and 2016. Diesel-range organic compounds were detected in 9 out of the 11 soil samples collected at the 11 monitoring wells. Gasoline-range organic compound concentrations exceeded the Tier 2 assessment level for total petroleum hydrocarbons in soil samples from site 1 (5,200 milligrams per kilogram), site 5 (580 milligrams per kilogram), and site 9 (1,800 milligrams per kilogram); the remaining sites had concentrations below the Tier 2 assessment level for total petroleum hydrocarbons. The highest concentrations of diesel-range organic compounds in soil samples from site 1 (3,600 milligrams per kilogram), site 5 (440 milligrams per kilogram), and site 14 (330 milligrams per kilogram), and only the sample from site 1 exceeded the Tier 2 assessment level for total petroleum hydrocarbons.

Petroleum hydrocarbon concentrations were measured in samples collected from 14 groundwater monitoring wells and 1 recovery sump between 2014 and 2018 in the study area around Fuels Area C. Benzene, toluene, ethylbenzene, total xylene (BTEX) compounds were detected in at least one sample collected from 10 of the 15 sites sampled in the study area from 2014 to 2018. Samples from monitoring well sites 2, $3,6,8$, and 9 did not have any quantifiable concentrations of BTEX compounds. Multiple BTEX compounds were detected consistently in samples collected from sites 10 and 11 . Few BTEX compounds were detected at sites outside of and downgradient from Fuels Area C (sites 12-14).

Measurable BTEX compound concentrations in most of the wells sampled in 2014-18 in the study area were either below the laboratory reporting level or slightly greater than the laboratory reporting level, except for samples collected at sites 7,10 , and 11. BTEX compound concentrations generally were the highest and most variable at site 11 compared to all the other sites sampled in the study area from 2014 to 2018.

Naphthalene was detected in 8 of the 15 groundwater sites sampled in the study area in 2014-18. Detections of measurable naphthalene concentrations were in 2014 and 2015 at site 1 ( 1 out of 3 samples), site 2 ( 1 out of 3 samples), site 5 (both samples), site 7 ( 1 out of 3 samples), and site 9 ( 2 out of 3 samples); detected concentrations for site 9 were all below the laboratory reporting level. Measurable concentrations of naphthalene generally were less than 5 micrograms per liter in wells sampled in the study area in 2014-18 except for samples collected at sites 5, 7, and 11 .

The variability of the presence of BTEX compounds and naphthalene in wells sampled in the study area during 2014-18 likely is caused by the variability in the subsurface material, local groundwater flow, operational fueling activities, and historical spills and releases in the area. The spatial and temporal variability in the BTEX compounds and naphthalene concentration from samples collected from 2014 to 2018 do not indicate a consistent pattern of subsurface flow or contaminant movement that would be expected if a contaminant plume migrated with the flow and movement of groundwater.

Gasoline-range organic and diesel-range organic compounds were detected in most of the groundwater samples collected in the study area around Fuels Area C in 2014-18; however, concentrations were often less than the laboratory reporting level. Median gasoline-range organic compound concentrations were greater than the laboratory reporting level at sites 1, 5, 9, 10, and 11. Median diesel-range organic compound concentrations were greater than the laboratory reporting level at most sites except sites 2, 4, 6, and 7. The highest concentrations of gasoline-range organic and diesel-range organic compounds generally were observed in samples collected from sites 10 and 11. Gasoline-range organic compound concentrations ranged from 1,500 to 9,700 micrograms per liter at site 10 and from less than 100 to 13,000 micrograms per liter at site 11. Diesel-range organic compound concentrations ranged from 9,600 to 55,000 micrograms per liter at site 10 and from 560 to 7,300 micrograms per liter at site 11 . 


\section{References Cited}

Advanced Geosciences Incorporated, 2020a, High-speed 2D/3D Resistivity/IP/SP Imaging System Package-56 Electrodes: accessed December 7, 2020, at https://www.a giusa.com/high-speed-2d3d-resistivityipsp-imaging-systempackage-56-electrodes.

Advanced Geosciences Incorporated, 2020b, AGI EarthImager 2D: accessed December 12, 2020, at https://www.a giusa.com/agi-earthimager-2d.

Anderson, T.M., Eldridge, W.G., Valder, J.F., and Wiles, M., 2019, Generalized potentiometric-surface map and groundwater flow directions in the Madison aquifer near Jewel Cave National Monument, South Dakota: U.S. Geological Survey Scientific Investigations Report 2019-5098, 16 p. [Also available at https://doi.org/10.3133/sir20195098.]

Bender, D.A., and Rowe, B.L., 2015, Soil and groundwaterquality data for petroleum hydrocarbon compounds within Fuels Area C, Ellsworth Air Force Base, South Dakota, 2014: U.S. Geological Survey Data Series 939, 15 p. [Also available at https://dx.doi.org/10.3133/ds939.]

BERS-Weston Services JVA, LLC, 2016, Final project report-Investigation of fuel impacts, immediate response action, Ellsworth Air Force Base, Rapid City, South Dakota: BERS-Weston Services JVA, LLC, 534 p., accessed January 15, 2021, at https://denr.sd.gov/spillimages/2015/ 2015.096 RESPONSELTR\&ATTACHMENTS.PDF.

Carter, J.M., Driscoll, D.G., Williamson, J.E., and Lindquist, V.A., 2002, Atlas of water resources in the Black Hills area, South Dakota: U.S. Geological Survey Hydrologic Investigations Atlas HA-747, 120 p. [Also available at https://doi.org/10.3133/ha747.]

Constable, S.C., Parker, R.L., and Constable, C.G., 1987, Occam's inversion-A practical algorithm for generating smooth models from electromagnetic sounding data: Geophysics, v. 52, no. 3, p. 289-300, accessed December 1, 2020, at https://doi.org/10.1190/1.1442303.

Cunningham, W.L., and Schalk, C.W., comps., 2011, Groundwater technical procedures of the U.S. Geological Survey: U.S. Geological Survey Techniques and Methods, book 1, chap. A1, 151 p. [Also available at https://doi.org/ $10.3133 / \mathrm{tm} 1 \mathrm{~A} 1$.

Custance, S.R., McCaw, P.A., Kopf, A.C., and Sullivan, M.J., 1992, Environmental fate of chemical mixtures - Crude oil, JP-5, mineral spirits, and diesel fuel: Journal of Soil Contamination, v. 1, no. 4, p. 379-386.

Esri, 2016, Topo to Raster: Esri, ArcGIS for Desktop, accessed March 11, 2020, at https://desktop.arcgis.com/en/arcmap/ 10.3/tools/spatial-analyst-toolbox/topo-to-raster.htm.
Farquharson, C.G., and Oldenburg, D.W., 1998, Non-linear inversion using general measures of data misfit and model structure: Geophysical Journal International, v. 134, no. 1, p. 213-227, accessed December 1, 2020, at https://doi.org/ 10.1046/j.1365-246x.1998.00555.x.

Loke, M.H., 2000, Electrical imaging surveys for environmental and engineering studies-A practical guide to 2-D and 3-D surveys: Geometrics, Inc., 67 p., accessed May 20, 2014, at https://pages.mtu.edu/ ctyoung/LOKENOTE.PDF.

Loke, M.H., 2004, Tutorial-2-D and 3-D electrical imaging surveys: accessed January 21, 2019, at https://sites.ua lberta.ca/ unsworth/UA-classes/223/loke_course_notes.pdf.

McGregor, E.E., and Cattermole, J.M., 1973, Geologic map of the Rapid City NW quadrangle, Meade and Pennington Counties, South Dakota: U.S. Geological Survey Map GQ-1093, 1 sheet, 1:24,000.

Medler, C.J., Tatge, W.S., and Bender, D.A., 2021, Electrical Resistivity Tomography (ERT) and Horizontal-to-Vertical Spectral Ratio (HVSR) data collected within and near Ellsworth Air Force Base, South Dakota, from 2014 to 2019: U.S. Geological Survey data release, https://doi.org/ 10.5066/P9XSJH17.

Mitra, S., and Roy, P., 2011, BTEX-A serious groundwater contaminant: Research Journal of Environmental Sciences, v. 5, no. 5, p. 394-398. [Also available at https://doi.org/ 10.3923/rjes.2011.394.398.]

Oblinger-Childress, C.J., Foreman, W.T., Connor, B.F., and Maloney, T.J., 1999, New reporting procedures based on long-term method detection levels and some considerations for interpretations of water-quality data provided by the U.S. Geological Survey National Water Quality Laboratory: U.S. Geological Survey Open-File Report 99-193, 19 p. [Also available at https://doi.org/10.3133/ofr99193.]

Powers, R., 2013, Installation overview-Ellsworth Air Force Base, South Dakota: accessed September 8, 2013, at http://usmilitary.about.com/od/airforcebaseprofiles/ss/ Ellsworth_4.htm.

Rahn, P.H., and Glick, M.J., 2000, Waste disposal potential in Cretaceous shale in western South Dakota, in Strobel, M.I., Davis, A.D., Sawyer, J.F., Rahn, P.H., Webb, C.J., and Naus, C.A., eds., Hydrology of the Black Hills, 1999 Black Hills Hydrology Conference, Rapid City, S. Dak., p. 184-192.

Redden, J.A., and DeWitt, E., 2009, Maps showing geology, structure, and geophysics of the central Black Hills, South Dakota: U.S. Geological Survey Scientific Investigations Map 2777, scale 1:100,000, accessed August 23, 2020, at https://doi.org/10.3133/sim2777. 
Rydlund, P.H., Jr., and Densmore, B.K., 2012, Methods of practice and guidelines for using survey-grade global navigation satellite systems (GNSS) to establish vertical datum in the United States Geological Survey: U.S. Geological Survey Techniques and Methods, book 11, chap. D1, $102 \mathrm{p}$. with appendixes. [Also available at https://doi.org/ 10.3133/tm11D1.]

Sheets, R.A., 2002, Use of electrical resistivity to detect underground mine voids in Ohio: U.S. Geological Survey Water-Resources Investigations Report 2002-4041, 33 p. [Also available at https://doi.org/10.3133/wri024041.]

South Dakota Department of Environment and Natural Resources, 2003, Release investigation and corrective action requirements: accessed August 12, 2013, at https://denr.sd.gov/des/gw/Spills/handbook/Hand_ Book.aspx.

South Dakota Department of Environmental and Natural Resources, 2019, Water well completion reports: accessed July 20, 2019, at https://apps.sd.gov/nr68welllogs/.

South Dakota Department of Environment and Natural Resources, 2020, Tanks and spills map: accessed November 29, 2020, at https://apps.sd.gov/ NR42InteractiveMap.

State of South Dakota, 1996, Remediation criteria for petroleum-contaminated soils (ARSD 74:56:05): accessed December 15, 2019, at https://sdlegislature.gov/Rules/ DisplayRule. aspx?Rule=74:56:05.

State of South Dakota, 2004, Groundwater quality standards (ARSD 74:54:01): accessed December 15, 2019, at https://sdlegislature.gov/rules/DisplayRule.aspx?Rule= $74 \% 3 \mathrm{~A} 54 \% 3 \mathrm{~A} 01$.

Tetra Tech Incorporated, 2008, Site Assessment Report OW531 (OWS 1709) at Ellsworth Air Force Base, South Dakota: Tetra Tech Incorporated, p. 948-1088, accessed November 29, 2020, at https://denr.sd.gov/spillimages/2003/ 2003.029_CompleteFile.pdf.

Tetra Tech Incorporated, 2012, Results of soil and groundwater assessment of Fuels Area C: Consultants report to Ellsworth Air Force Base, 32 p.

U.S. Air Force, 2012, Environmental assessment addressing activities associated with development of a regional wastewater treatment plant Ellsworth Air Force Base, South Dakota: accessed November 29, 2020, at https://www.ellsworth.af.mil/Portals/146/documents/AFD120413-041.pdf?ver=2016-06-17-155607-247.
U.S. Environmental Protection Agency, 2003, EPA Method 8015D (SW-846) - Nonhalogenated Organics Using GC/ FID: accessed October 16, 2020, at https://www.epa.gov/ esam/epa-method-8015d-sw-846-nonhalogenated-organicsusing-gcfid.

U.S. Environmental Protection Agency, 2006, Validated Test Method 8260C - Volatile organic compounds by gas chromatography/mass spectrometry (GC/MS): accessed October 29, 2020, at https:/www.epa.gov/hw-sw846/ validated-test-method-8260c-volatile-organic-compoundsgas-chromatographymass-spectrometry.

U.S. Environmental Protection Agency, 2012, Drinking water contaminants - National primary drinking water regulations: U.S. Environmental Protection Agency, accessed December 5, 2019, at https://www.epa.gov/ground-waterand-drinking-water/national-primary-drinking-waterregulations.

U.S. Environmental Protection Agency, 2013, Drinking water contaminants: accessed July 24, 2013, at https://water.epa.gov/drink/contaminants/.

U.S. Environmental Protection Agency, 2016, Benzene: accessed October 23, 2019, at https://www.epa.gov/sites/ production/files/2016-09/documents/benzene.pdf.

U.S. Geological Survey, variously dated, National field manual for the collection of water-quality data: U.S. Geological Survey Techniques of Water-Resources Investigations, book 9, chaps. A1-A10. [Also available at https://pubs.water .usgs.gov/twri9A.]

U.S. Geological Survey, 2020, USGS water data for the Nation: U.S. Geological Survey National Water Information System database, accessed October 31, 2020, at https://doi.org/10.5066/F7P55KJN.

Zemo, D.A., O’Reilly, K.T., Mohler, R.E., Magaw, R.I., Devine, C.E., Ahn, S., and Tiwary, A.K., 2017, Life cycle of petroleum biodegradation metabolite plumes, and implications for risk management at fuel release sites: Society of Environmental Toxicology and Chemistry, v. 13, no. 4, p. 714-727, accessed November 14, 2020, at https:// setac.onlinelibrary.wiley.com/doi/pdfdirect/10.1002/ ieam. 1848 . 
Appendix 1. Water-Level Data around Fuels Area C, 2014-18 
Table 1.1. Water-level data measured at 14 monitoring wells in the study area around Fuels Area C, 2014-18.

[All water-level data for these sites are available from the U.S. Geological Survey National Water Information System database (U.S. Geological Survey, 2020); ID, identification; USGS, U.S. Geological Survey; MM, month; DD, day; YYYY, year; --, not available; >, greater than; elevation refers to the distance above the land-surface datum, North American Vertical Datum of 1988]

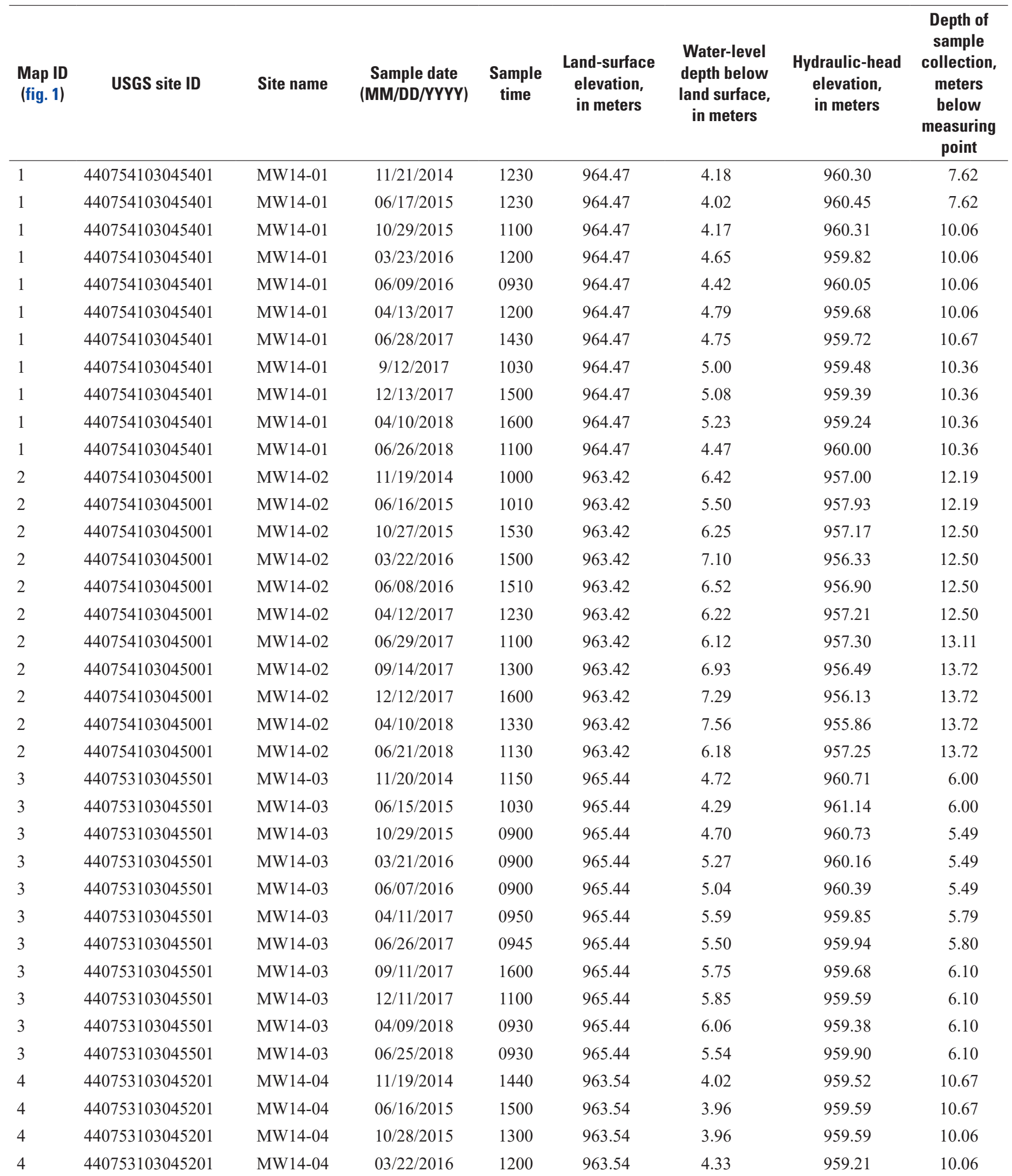


Table 1.1. Water-level data measured at 14 monitoring wells in the study area around Fuels Area C, 2014-18.-Continued

[All water-level data for these sites are available from the U.S. Geological Survey National Water Information System database (U.S. Geological Survey, 2020); ID, identification; USGS, U.S. Geological Survey; MM, month; DD, day; YYYY, year; --, not available; >, greater than; elevation refers to the distance above the land-surface datum, North American Vertical Datum of 1988]

\begin{tabular}{|c|c|c|c|c|c|c|c|c|}
\hline $\begin{array}{c}\text { Map ID } \\
\text { (fig. 1) }\end{array}$ & USGS site ID & Site name & $\begin{array}{c}\text { Sample date } \\
\text { (MM/DD/YYYY) }\end{array}$ & $\begin{array}{l}\text { Sample } \\
\text { time }\end{array}$ & $\begin{array}{l}\text { Land-surface } \\
\text { elevation, in } \\
\text { meters }\end{array}$ & $\begin{array}{l}\text { Water-level } \\
\text { depth below } \\
\text { land surface, } \\
\text { in meters }\end{array}$ & $\begin{array}{l}\text { Hydraulic-head } \\
\text { elevation, } \\
\text { in meters }\end{array}$ & $\begin{array}{c}\text { Depth of } \\
\text { sample } \\
\text { collection, } \\
\text { meters } \\
\text { below } \\
\text { measuring } \\
\text { point }\end{array}$ \\
\hline 4 & 440753103045201 & MW14-04 & 06/08/2016 & 1245 & 963.54 & 4.21 & 959.33 & 10.06 \\
\hline 4 & 440753103045201 & MW14-04 & $06 / 27 / 2017$ & 1330 & 963.54 & 4.37 & 959.18 & 10.36 \\
\hline 4 & 440753103045201 & MW14-04 & 09/13/2017 & 1330 & 963.54 & 4.68 & 958.86 & 10.36 \\
\hline 4 & 440753103045201 & MW14-04 & $12 / 13 / 2017$ & 1300 & 963.54 & 4.77 & 958.78 & 10.36 \\
\hline 4 & 440753103045201 & MW14-04 & $04 / 10 / 2018$ & 0915 & 963.54 & 4.95 & 958.60 & 10.36 \\
\hline 5 & 440751103045301 & MW14-05 & $10 / 28 / 2015$ & 0830 & 964.73 & 2.92 & 961.81 & 3.66 \\
\hline 5 & 440751103045301 & MW14-05 & $03 / 21 / 2016$ & 1000 & 964.73 & 3.22 & 961.51 & 3.66 \\
\hline 5 & 440751103045301 & MW14-05 & 06/07/2016 & 1000 & 964.73 & 2.87 & 961.86 & 3.66 \\
\hline 5 & 440751103045301 & MW14-05 & $04 / 11 / 2017$ & 1100 & 964.73 & 3.88 & 960.85 & 3.66 \\
\hline 5 & 440751103045301 & MW14-05 & $06 / 26 / 2017$ & 1030 & 964.73 & 3.08 & 961.66 & 3.66 \\
\hline 5 & 440751103045301 & MW14-05 & 09/18/2017 & 1000 & 964.73 & 3.42 & 961.31 & 3.66 \\
\hline 5 & 440751103045301 & MW14-05 & $12 / 11 / 2017$ & 1200 & 964.73 & 4.05 & 960.68 & 3.66 \\
\hline 5 & 440751103045301 & MW14-05 & $04 / 09 / 2018$ & 1000 & 964.73 & 4.41 & 960.32 & 3.66 \\
\hline 5 & 440751103045301 & MW14-05 & $06 / 25 / 2018$ & 1000 & 964.73 & 2.44 & 962.29 & 3.66 \\
\hline 6 & 440753103045202 & MW14-06 & $06 / 28 / 2017$ & 1230 & 963.72 & 4.66 & 959.06 & 10.67 \\
\hline 6 & 440753103045202 & MW14-06 & 09/13/2017 & 1600 & 963.72 & 4.89 & 958.83 & 10.36 \\
\hline 6 & 440753103045202 & MW14-06 & $12 / 13 / 2017$ & 1030 & 963.72 & 4.99 & 958.73 & 10.36 \\
\hline 6 & 440753103045202 & MW14-06 & $04 / 10 / 2018$ & 1130 & 963.72 & 5.19 & 958.53 & 10.36 \\
\hline 6 & 440753103045202 & MW14-06 & $06 / 22 / 2018$ & 1300 & 963.72 & 4.72 & 959.00 & 10.36 \\
\hline 7 & 440753103045001 & MW14-07 & $11 / 19 / 2014$ & 1230 & 962.41 & 5.94 & 956.47 & 10.67 \\
\hline 7 & 440753103045001 & MW14-07 & $06 / 17 / 2015$ & 0950 & 962.41 & 5.39 & 957.02 & 10.67 \\
\hline 7 & 440753103045001 & MW14-07 & $10 / 27 / 2015$ & 1330 & 962.41 & 5.66 & 956.75 & 10.67 \\
\hline 7 & 440753103045001 & MW14-07 & $03 / 21 / 2016$ & 1430 & 962.41 & 6.27 & 956.13 & 10.67 \\
\hline 7 & 440753103045001 & MW14-07 & 06/07/2016 & 1400 & 962.41 & 5.88 & 956.53 & 10.67 \\
\hline 7 & 440753103045001 & MW14-07 & $04 / 12 / 2017$ & 1000 & 962.41 & 6.10 & 956.30 & 10.67 \\
\hline 7 & 440753103045001 & MW14-07 & $06 / 27 / 2017$ & 1100 & 962.41 & 5.66 & 956.74 & 10.67 \\
\hline 7 & 440753103045001 & MW14-07 & $09 / 11 / 2017$ & 1400 & 962.41 & 6.29 & 956.11 & 11.58 \\
\hline
\end{tabular}


Table 1.1. Water-level data measured at 14 monitoring wells in the study area around Fuels Area C, 2014-18.-Continued

[All water-level data for these sites are available from the U.S. Geological Survey National Water Information System database (U.S. Geological Survey, 2020); ID, identification; USGS, U.S. Geological Survey; MM, month; DD, day; YYYY, year; --, not available; >, greater than; elevation refers to the distance above the land-surface datum, North American Vertical Datum of 1988]

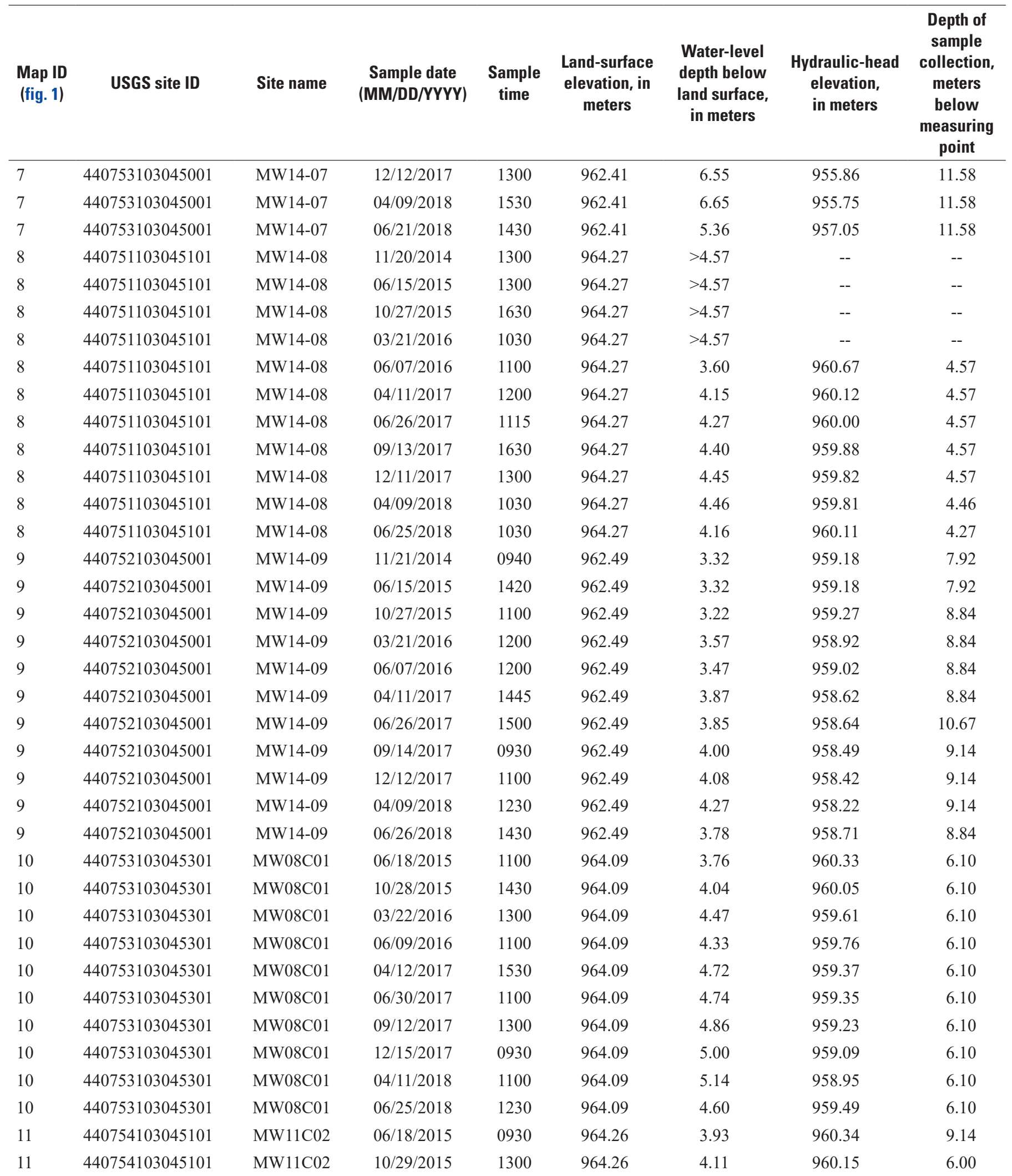


Table 1.1. Water-level data measured at 14 monitoring wells in the study area around Fuels Area C, 2014-18.-Continued

[All water-level data for these sites are available from the U.S. Geological Survey National Water Information System database (U.S. Geological Survey, 2020); ID, identification; USGS, U.S. Geological Survey; MM, month; DD, day; YYYY, year; --, not available; >, greater than; elevation refers to the distance above the land-surface datum, North American Vertical Datum of 1988]

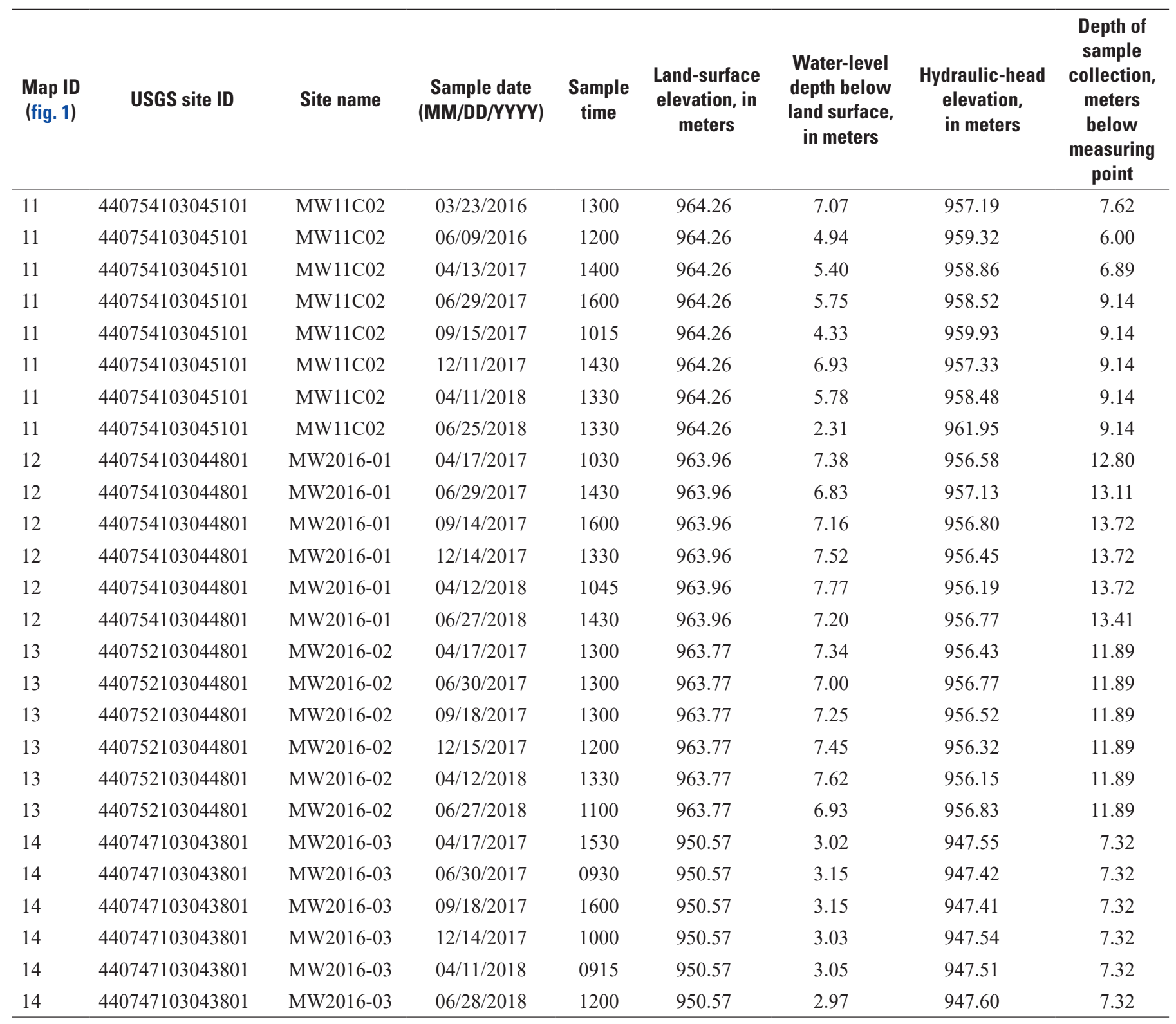

\section{References Cited}

U.S. Geological Survey, 2020, USGS water data for the Nation: U.S. Geological Survey National Water Information System database, accessed October 31, 2020, at https://doi. org/10.5066/F7P55KJN. 


\section{Appendix 2. Water-Quality Data around Fuels Area C, 2014-18}

Water-quality data around Fuels Area C, 2014-18, are shown in table 2.1 (available for download at https://doi.org/ 10.3133/sir20215060). 

For more information about this publication, contact:

Director, USGS Dakota Water Science Center

821 East Interstate Avenue, Bismarck, ND 58503

1608 Mountain View Road, Rapid City, SD 57702

605-394-3200

For additional information, visit: https://www.usgs.gov/centers/dakotawater

Publishing support provided by the Rolla

and Lafayette Publishing Service Centers 


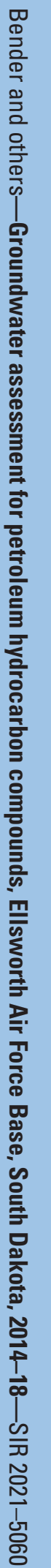

